\title{
Intestinal Health of Pigs Upon Weaning: Challenges and Nutritional Intervention
}

\author{
Lan Zheng, Marcos Elias Duarte, Ana Sevarolli Loftus and Sung Woo Kim* \\ Department of Animal Science, North Carolina State University, Raleigh, NC, United States
}

The primary goal of nursery pig management is making a smooth weaning transition to minimize weaning associated depressed growth and diseases. Weaning causes morphological and functional changes of the small intestine of pigs, where most of the nutrients are being digested and absorbed. While various stressors induce post-weaning growth depression, the abrupt change from milk to solid feed is one of the most apparent challenges to pigs. Feeding functional feed additives may be viable solutions to promote the growth of nursery pigs by enhancing nutrient digestion, intestinal morphology, immune status, and by restoring intestinal balance. The aim of this review was to provide

OPEN ACCESS

Edited by: Domenico Bergero,

University of Turin, Italy

Reviewed by:

Francesca Romana Massacci, Istituto Sperimentale di Zooprofilassi dell'Umbria e delle Marche

(IZSUM), Italy

Maicon Sbardella, Federal University of Mato Grosso, Brazi

*Correspondence. Sung Woo Kim sungwoo_kim@ncsu.edu

Specialty section: This article was submitted to Animal Nutrition and Metabolism,

a section of the journal

Frontiers in Veterinary Science

Received: 11 November 2020 Accepted: 21 January 2021

Published: 12 February 2021

Citation:

Zheng L, Duarte ME, Sevarolli Loftus A and Kim SW (2021) Intestinal Health of Pigs Upon Weaning: Challenges and

Nutritional Intervention.

Front. Vet. Sci. 8:628258. doi: 10.3389/fvets.2021.628258 available scientific information on the roles of functional feed additives in enhancing intestinal health and growth during nursery phase. Among many potential functional feed additives, the palatability of the ingredient and the optimum supplemental level are varied, and these should be considered when applying into nursery pig diets. Considering different stressors pigs deal with in the post-weaning period, research on nutritional intervention using a single feed additive or a combination of different additives that can enhance feed intake, increase weight gain, and reduce mortality and morbidity are needed to provide viable solutions for pig producers. Further research in relation to the feed palatability, supplemental level, as well as interactions between different ingredients are needed.

Keywords: feed additives, intestinal health, newly weaned pigs, nutritional intervention, weaning stress

\section{INTRODUCTION}

Weaning is considered as one of the most critical periods in pig management. It is associated with environmental, social, and dietary stress (1-3), and those various stressors result in low feed intake, body weight loss, and a high incidence of diarrhea, which consequently, can lead to mortality $(4,5)$. Even though trends for weaning ages at large commercial farms increase to 3-4 weeks of age, pigs are naturally weaned at the age of 12-17 weeks $(6,7)$. Upon weaning, at typical commercial farms, pigs deal with multiple stressors due to changes such as separation from the sow, relocation with new littermates, and sudden dietary change from sow milk to solid feeds (8). Inadequate feed intake after weaning results in insufficient dietary nutrients utilization and local inflammation (9-11). As a consequence, weaning causes profound changes in the gastrointestinal tract (GIT) of pigs. Intestine is a major site of nutrient digestion and absorption. Intestinal disorders after weaning are caused by alterations in architecture and functions with villus atrophy and crypt hyperplasia and increase in intestinal permeability (12). Moreover, intestinal microbiota disruption and changes are possibly linked to diarrhea and pathogenic infections after weaning (13-16). 
Increased research needs and interests in understanding intestinal health in pigs are well-reflected in the number of peer reviewed papers searchable in PubMed (using intestinal health in pigs as keywords in the title or abstract). Since 1960 and until 2005, there have been $<10$ papers searched in PubMed, which has been 10 folds increased by 2018 and then 180 papers in 2020 . This review focuses on feed additives as nutritional strategies to overcome weaning challenges.

\section{WEANING ASSOCIATED FUNCTIONAL CHANGES IN THE SMALL INTESTINE}

\section{Morphological Changes}

Enterocytes are composed of villi projecting into the lumen, and a folded cell monolayer structured into crypts in pigs (17). Villi are mainly lined by enterocytes, goblet cells, and enteroendocrine cells, and the crypts are the main site containing stem cells, proliferative and undifferentiated cells, and a subset of differentiated secretory cells (Paneth, goblet and enteroendocrine cells) (18) as shown in Figure 1. When stem cells divide, they go through a cell division into a new stem cell and a committed daughter cell (19). The differentiation and maturation of each cell type happens as the cells move either migrate up the cryptvillus axis (enterocytes, mucous, and enteroendocrine cells) or downwards to the bottom of the crypt (Paneth cells) (20). In the mammalian small intestine, active enterocyte proliferation is restricted to the crypts at the base of the villi (21). Stem cells in the crypts undergo cell division and differentiation to form mature absorptive enterocytes, mucus- producing goblet cells, and enteroendocrine cells, and those cells migrate toward the villus tip, where they are discarded into the intestinal lumen (22).

After weaning, a consistent series of intestinal alterations occur. Architectural alterations associated with weaning reported in previous studies are presented in Table 1. Within $24 \mathrm{~h}$ of weaning, villus height was shown to reduce by $75 \%$ compared to pre-weaning status (5). The height reduction of villi is a result of increased cell loss and/or reduced crypt cell production (5). The villus atrophy and the reduction in crypt cell production during the post-weaning period result in loss of mature enterocytes, which could cause a decrease in nutrient absorption $(26,28,29)$. Reduced activity of brush-border enzymes, such as lactase and peptidases and nutrient transporters, have been observed to be correlated with shortened villus height $(30,31)$.

\section{Barrier Function}

Tight junction proteins between epithelial cells form the barriers, which closes the paracellular space between epithelial cells regulating permeability through the epithelial layer (32). These proteins consist of transmembrane proteins such as occludin and claudins, as well as cytoplasmic proteins such as zonula occludens ( $\mathrm{ZO}$ ) (33). As a barrier between the luminal and basolateral compartments, tight junction proteins control the passive diffusion of ions and other small solutes, through the paracellular pathway (34). These tight junction proteins serving as a filter to allow important dietary nutrients, electrolytes, and water to translocate from the lumen of the intestine into circulation (35-37). Increases in intestinal permeability can result in inflammatory responses by allowing the entry of toxins, allergenic compounds, or bacteria $(38,39)$. Intestinal barrier function can be compromised by various factors, such as age, diet, pathogens, and diseases $(40,41)$.

Weaning induced impaired barrier function of epithelial cells promotes the entering of pathogenic bacteria and allergenic compounds from the lumen into the body $(12,42)$. Weaning causes compromised paracellular barrier function $(2,43)$. Active absorption decreases when pigs are weaned at 3 weeks of age or earlier as a process of natural intestinal maturation stimulated by weaning (Table 2); however, if pigs are weaned after 3 weeks of age, the active absorption is no more affected by weaning indicating weaning at an early age can disrupt barrier function (43).

\section{Mucosal Immunity at Weaning}

Up to $70 \%$ of the immune cells are localized in the mucosa and submucosa of the intestine $(49,50)$. The gut-associated lymphoid tissue (GALT) consists of both isolated and aggregated lymphoid follicles forming Peyer's patches (PP) and mesenteric lymph nodes (51). The induction of intestinal immune reactions starts with antigen presentation by microfold cells ( $M$ cells) (52). Lamina propria serves as a mucosal compartment for the regulation of immune responses (predominantly $\operatorname{IgA}$ ), with few T-cells or dendritic cells, but with myeloid cells with the characteristics of macrophages and granulocytes (53). The production of secretory antibodies, mostly IgA and IgM, is the major defending characteristics of the mucosal immune system. These antibodies are actively transported by immature epithelial cells in the crypts, and immune exclusion is carried out by the generated in cooperation with innate non-specific defense mechanisms (54). Two important periods of maximum exposure to antigens occur immediately after birth and at weaning. At weaning, the abrupt changes in the diet and environment induce alterations in the mucosal immune response (15).

The immune system in the intestine of pigs reaches an adult-like structure at 7-week-old age (55). Conventionally, weaning of pigs is done in the range of 3-4 weeks old, when cytotoxic (CD8+) $\mathrm{T}$ cells are primarily absent (55). Weaning also affects the systemic development of innate and adaptive immunity mainly as a consequence of the withdrawal of milk (56). Up-regulated expression of pro-inflammatory cytokines is observed in pigs at weaning (42). Recent studies have shown that pro-inflammatory cytokines, including tumor necrosis factor$\alpha$, interferon- $\gamma$, interleukin- $1 \beta$, induce disturbance in intestinal barrier and increase intestinal epithelial permeability (57-59). In addition, inflammation is often associated with intestinal oxidative stress $(60,61)$. Disruption of cellular redox status can cause excess production of pro-inflammatory cytokines, which could further impair intestinal function $(62,63)$. The appropriate development of the intestinal immune system and maintaining normal redox state are essential for optimum growth and performance of the pigs. Controlling the intestinal inflammation by the over expression of intestinal pro-inflammatory cytokines may alleviate subsequent intestinal disorders induced by the weaning stress. 


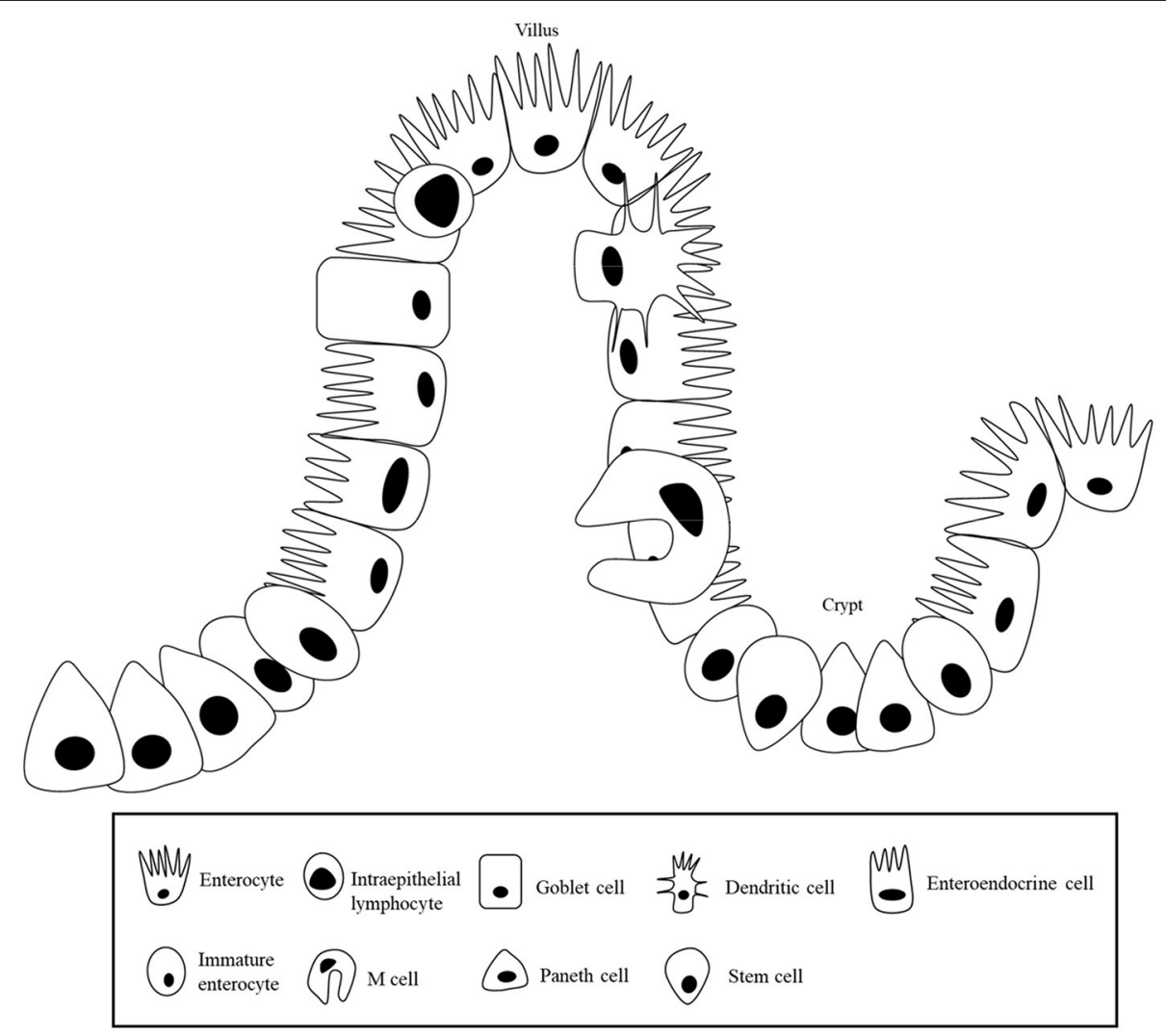

FIGURE 1 | Intestinal epithelial layer.

TABLE 1 | Morphological changes in the small intestine of pigs after weaning.

\begin{tabular}{llll}
\hline Weaning age (day) & Intestinal section & Results & References \\
\hline 21 & Small intestine & Decreased villus height and increased crypt depth during day 11 post-weaning & Decreased villus height during day 3 post-weaning when weaned at 21 or 35 day \\
21 or 35 & Jejunum & Decreased villus height to crypt depth ratio at day 7 post-weaning & (5) \\
14 & Small intestine & Increased crypt depth at day 5 post-weaning & (24) \\
28 & $75 \%$ of small intestine & Decreased villus height at day 2 and 4 and decreased villus height to crypt depth ratio at day 2 & (12) \\
26 & Small intestine & and 4 post-weaning & Decreased villus height from day 2 post-weaning with minimal length was observed at day 3 \\
29 & Jejunum & post-weaning and increased crypt depth at day 5 post-weaning & (26) \\
21 & Jejunum & Decreased villus height from day 2 post-weaning and increased crypt depth from day 5
\end{tabular}

\section{Intestinal Microbiota}

In pigs, the hindgut is the major site of microbial fermentation, and the microbial population in the small intestine is less diverse than the hindgut (64). The small intestine is a major place for nutrient absorption, and microbiota present in the outer mucosal layer of the small intestine are more susceptible to dietary influence $(65,66)$. The small intestinal mucosa is frequently exposed to various exogenous antigens and microbial components from feed ingredients. Changes in mucosa-associated microbiota may have enormous effects on host growth and development $(14,16,67)$. Most of the past studies are focused on the dietary intervention on luminal and fecal microbiota, few studies evaluated on mucosa-associated microbiota. Post-weaning dietary intervention showed a long lasting effect on mucosa-associated microbiota, but not on digesta in the small intestine $(16,66)$. The microbial community within the outer layer of the mucosa is closely connected with host tissues, mucosa-associated bacteria are in direct competition 
TABLE 2 | Impact of weaning age on intestinal health ${ }^{\mathrm{a}}$.

\begin{tabular}{|c|c|c|c|c|}
\hline Parameter & Weaning age (day) & $\begin{array}{l}\text { Experimental } \\
\text { period (day) }\end{array}$ & Early weaning impact & References \\
\hline \multirow[t]{4}{*}{ Morphology } & 21 vs. 28 & 56 & ND & $(44)$ \\
\hline & 18 vs. 20 & 4 & $\downarrow$ Villus height when challenged with ETEC & $(45)$ \\
\hline & 15,18 vs. 23 & 35 & $\uparrow$ Lamina propria cell counts & $(46)$ \\
\hline & 28 vs. 49 & 7 & $\downarrow$ Villus height & $(47)$ \\
\hline \multirow[t]{4}{*}{ Barrier function } & 21 vs. 28 & 56 & $\uparrow$ Expression of tight junction proteins in the jejunum & $(44)$ \\
\hline & 18 vs. 20 & 4 & $\downarrow$ TER when challenged with ETEC & $(45)$ \\
\hline & 15,18 vs. 23 & 35 & $\downarrow$ TER and $\uparrow$ mucosal-to-serosal flux of mannitol and inulin & $(46)$ \\
\hline & 28 vs. 49 & 7 & $\uparrow$ Mucosal-to-serosal transport of horseradish peroxidase & $(47)$ \\
\hline \multirow[t]{3}{*}{ Mucosal immunity } & 21 vs. 28 & 56 & ND & $(44)$ \\
\hline & 18 vs. 20 & 4 & $\begin{array}{l}\uparrow \text { Mast cell activation when challenged with ETEC in pigs weaned at day } 20 \text {, } \\
\text { but not at } 18\end{array}$ & $(45)$ \\
\hline & 15,18 vs. 23 & 35 & $\uparrow$ Numbers of mast cells, corticotrophin-releasing factor, and cortisol levels & $(46)$ \\
\hline Microbiota & $14,21,28$, vs. 42 & 7 & $\downarrow$ Microbial diversity and richness & $(48)$ \\
\hline
\end{tabular}

aND, no differences were observed; ETEC, Enterotoxigenic F18 E. coli; TER, transepithelial electrical resistance.

with substrates with the host (68). Distinct microbial populations present throughout the gastrointestinal tract due to the different physicochemical conditions and substrate availability $(69,70)$. The fecal microbiota is distinctly different from that of the luminal of the small intestine. The similarity index of the fecal microbiota and luminal microbiota of the large intestine was 0.75 , whereas it was only 0.38 when comparing the fecal and luminal microbiota of the small intestine (69). Mucosa-associated microbiota of cecum was distinctively different from that of the digesta in the cecum (64). From the outer mucosal layer into the lumen, a rapid declining oxygen gradient exists, which generating a distinct microenvironment between mucosal tissue and lumen (71). Mucosa-associated microbiota provides a line of defense against pathogens and modulates the immune status of the host $(54,72-74)$. The microbiota induces production of IgA by the mucosal immune system, which is secreted into the lumen to limit bacterial colonization and prevent penetration of bacteria through the epithelial layer (54, 75-77).

At weaning, the abrupt changes in the diet and environment induce alterations in the intestinal microbiota $(15,78)$. During the weaning transition, a major shift in the dominant genus (Bacteroides to Prevotella) was observed (79). Yang et al. (80) compared microbiota composition of healthy and diarrheic piglets and found the diarrheic piglets had an altered competitive relationship between Prevotella and Escherichia before weaning and had lower relative abundances of five genera that play key roles in nutrient metabolism (Bacteroides, Ruminococcus, Bulleidia, and Treponema) than healthy piglets after weaning. In a similar study (81), diarrheic pigs had a lower Bacteroidales, the fiber-degrader family, than non-diarrheic pigs during weaning, which was considered as a biomarker of diarrhea. Reductions in Lactobacilli is one of the most evident change after weaning (78). It was postulated the alterations in the composition and activity of the GIT microbial community is correlated with pathogenic infections after weaning $(4,82)$. A lower stability of the microbial community structure was observed in the ileal digesta of weaned pigs than that of unweaned pigs (78). The intestinal bacterial community composition was shown to become stable at 6 months of age (69). Table 2 summarizes the impact of weaning age on intestinal structure and function.

\section{NUTRITIONAL INTERVENTION}

To assist in overcoming the weaning-associated intestinal dysfunction and depressed growth, effective dietary strategies need to be explored. Feed additives including protein hydrolysates, emulsifiers, prebiotics, probiotics, feed enzymes, nucleotides, organic acids, phytogenic feed additives, immunoglobulin-containing compounds, and/or mycotoxin deactivators are commonly used in the nursery pig diets to promote growth and intestinal health (see Table 3). The following session reviews the effects of selected feed additives.

\section{Protein Hydrolysates}

Protein hydrolysates are produced from a variety of protein sources by chemical, microbial or enzymatic hydrolysis to eliminate or reduce anti-nutritional factors (127). Typical protein hydrolysates used in animal diets are animal protein hydrolysates (such as salmon viscera and porcine intestines) and plant protein hydrolysates (such as soybean protein hydrolysates) (128). Through the production of protein hydrolysates, antinutritional factors are totally or partially hydrolyzed, which make those hydrolysates a high-quality protein source for nursery pigs (129-131). Digestion of protein is mainly completed in the small intestine (132). After weaning, decreased enzymatic activity of peptidases (aminopeptidase $\mathrm{N}$ and dipeptidylpeptidase IV) were detected (26). Improvements in crude protein digestibility by soy protein hydrolysates supplementation have been reported in nursery pigs (133-135). Blood plasma is a commonly used animal protein hydrolysate in nursery pig diets. It has been shown to increase growth performance (136), enhance intestinal barrier function (121), and modify intestinal immune function 
TABLE 3 | Selected feed additives targeting intestinal health of newly weaned pigs with additional references.

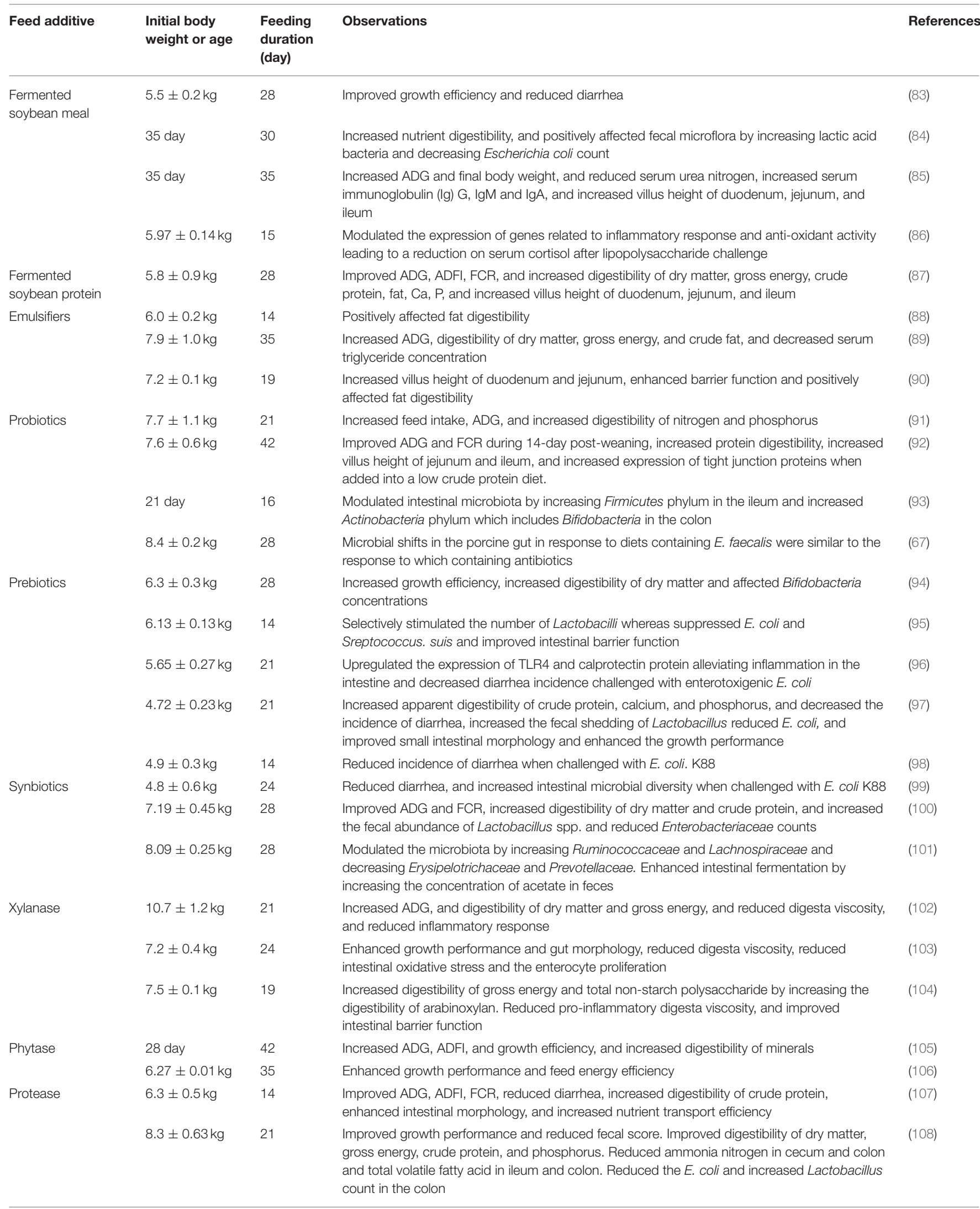


TABLE 3 | Continued

\begin{tabular}{|c|c|c|c|c|}
\hline Feed additive & $\begin{array}{l}\text { Initial body } \\
\text { weight or age }\end{array}$ & $\begin{array}{l}\text { Feeding } \\
\text { duration } \\
\text { (day) }\end{array}$ & Observations & References \\
\hline & $6.42 \pm 0.12 \mathrm{~kg}$ & 42 & $\begin{array}{l}\text { Enhanced growth performance and digestibility of dry matter, and nitrogen. Reduced blood } \\
\text { creatinine and fecal } \mathrm{NH}_{3}\end{array}$ & $(109)$ \\
\hline \multirow[t]{3}{*}{ Nucleotides } & $4.8 \pm 0.4 \mathrm{~kg}$ & 21 & Improved ADFI, positively affected ADG, and positively enhanced villus structure & $(110)$ \\
\hline & $7.3 \pm 0.1 \mathrm{~kg}$ & 28 & Improved ADG and ADFI & $(111)$ \\
\hline & $7.3 \pm 0.3 \mathrm{~kg}$ & 42 & $\begin{array}{l}\text { Increased final body weight, ADG, and growth efficiency, and increased digestibility of dry } \\
\text { mater and energy }\end{array}$ & $(112)$ \\
\hline \multirow[t]{3}{*}{ Organic acids } & $7.2 \pm 0.2 \mathrm{~kg}$ & 42 & $\begin{array}{l}\text { Improved ADG and FCR, increased villus height, increased acetic and propionic acid } \\
\text { concentrations, and altered microbial community structure }\end{array}$ & $(113)$ \\
\hline & $6.3 \pm 0.6 \mathrm{~kg}$ & 14 & Reduced inflammatory cytokines and altered microbial community composition & $(114)$ \\
\hline & $8.63 \pm 1.56 \mathrm{~kg}$ & 28 & $\begin{array}{l}\text { Improved ADG and FCR. Reduced diarrhea score by reducing E. coli count in feces. Improved } \\
\text { digestibility of dry matter, ether extract, total carbohydrates, fiber, and phosphorus and } \\
\text { improved intestinal morphology }\end{array}$ & $(115)$ \\
\hline \multirow{5}{*}{$\begin{array}{l}\text { Phytogenic feed } \\
\text { additives }\end{array}$} & 21 day & 11 & Reduced diarrhea and inflammation when challenged with E. coli & $(116)$ \\
\hline & $7.4 \pm 1.3 \mathrm{~kg}$ & 35 & Increased post-weaning feed intake & $(117)$ \\
\hline & $8.4 \pm 1.6 \mathrm{~kg}$ & 35 & $\begin{array}{l}\text { Increased weight gain, improved fecal consistency, and increased digestibility of dry matter and } \\
\text { crude protein }\end{array}$ & $(118)$ \\
\hline & $8.2 \pm 2.3 \mathrm{~kg}$ & 22 & Decreased pro-inflammatory cytokines & $(119)$ \\
\hline & 25 day & 42 & Increased growth efficiency and increased nutrient digestibility & $(120)$ \\
\hline \multirow[t]{3}{*}{ Blood plasma } & $5.5 \pm 0.1 \mathrm{~kg}$ & 14 & Reduced diarrhea and decreased pro-inflammatory cytokines & $(121)$ \\
\hline & $6.0 \pm 0.1 \mathrm{~kg}$ & 14 & Increased growth efficiency and reduced activation of the immune system & $(122)$ \\
\hline & $6.8 \pm 0.1 \mathrm{~kg}$ & 12 & Improved ADG, ADFI, and growth efficiency & $(10)$ \\
\hline \multirow{4}{*}{$\begin{array}{l}\text { Mycotoxin } \\
\text { deactivators }\end{array}$} & $8.2 \pm 0.1 \mathrm{~kg}$ & 34 & Reduced oxidative stress and immune activation & $(123)$ \\
\hline & $9.9 \mathrm{~kg}$ & 27 & Improved body weight, ADFI, and FCR & $(124)$ \\
\hline & $6.0 \pm 0.3 \mathrm{~kg}$ & 35 & Improved body weight, ADG, and ADFI & $(125)$ \\
\hline & $9.1 \pm 0.1 \mathrm{~kg}$ & 42 & Improved body weight, and ADG. Reduced TNF $\alpha$, and 8-OHdG & $(126)$ \\
\hline
\end{tabular}

(122) when fed to newly weaned pigs (further information see 3.9). Additionally, some peptides derived from protein hydrolysis especially milk and soy protein possess various biological functions including antimicrobial, antihypertensive, and immunomodulatory activities $(86,128,137,138)$.

\section{Soy Protein Hydrolysates}

Soybean meal is one of the most commonly used ingredients in animal feed; however, digestive disturbances are often observed when it is fed to young animals especially newly weaned pigs (139-141). Soybean meal contains various anti-nutritional factors including trypsin inhibitors, lectins, indigestible carbohydrate complexes, and soybean globulins (130, 139, 142, 143). Trypsin inhibitors and lectins can be inactivated by proper heat treatment and fat extraction $(140,144)$. However, the presence of indigestible carbohydrate complexes, antigenic soybean globulins, and residual trypsin inhibitor limits its use in young pig diets $(139,144,145)$. Glycinin and $\beta$-conglycinin, antigenic proteins, are the major antinutritional factors that cause allergic responses in young animals $(139,146,147)$. These proteins can cause hypersensitivity that induce abnormal intestinal morphological change and diarrhea when fed to young pigs $(139,148,149)$. Fermented soybean meal using microorganisms such as Aspergillus oryzae, Bacillus subtilis, and $L$. casei and enzyme-treated soybean meal are shown to have reduced anti-nutritional factors and increased concentrations of CP and AA than conventional soybean meal $(83,150)$. Through the microbial fermentation or enzymatic treatment of soybean meal, the antigenic proteins are hydrolyzed into small size peptides and the glycosidic bonds in the carbohydrate fraction in soybean meal are broken down by enzymes produced by fungus and bacteria, or by a mixture of enzymes $(129,151)$. Fermented and enzyme-treated soybean meal have been shown to improve growth performance and feed efficiency of nursery pigs when partially replaced conventional soybean meal in the diets $(83,84)$. Soy oligopeptides, a soy protein hydrolysate, was shown to improve amino acid absorption compared to an intact soy protein or corresponding amino acid mixtures in a human study (152). Amino acid absorption in the portal blood from a soy protein hydrolysate was more efficient than the constituent amino acids from an amino acid mixture and those from an intact soy protein in rats (153). In addition, enhanced intestinal morphology was observed when fed soy protein hydrolysates to nursery pigs $(85,87)$. Despite the improved nutritional values, the bitter taste of soy hydrolysates resulting from the hydrolysis of soy proteins has been a major problem 
in food applications $(154,155)$. The hydrophobic amino acids are shown to be involved in the bitter taste of various peptides (156). Concealed hydrophobic side chains in the interior of the protein are released with the protein hydrolysis which elucidates bitterness $(157,158)$. Therefore, the feed palatability testing may be necessary to ascertain if soy hydrolysates can promote growth of pigs without negatively affecting feed intake of nursery pigs.

\section{Emulsifiers}

Animal fats and vegetable oils are commonly added to meet energy concentration in the diet. To be absorbed in the gastrointestinal tract, dietary fat has to be emulsified by detergent action of the endogenous emulsifiers (such as bile salts) and hydrolyzed by lipase into fatty acids and mono- and diglycerides. Sow's milk contains $\sim 40 \%$ fat on a dry matter basis $(159,160)$; whereas, typical nursery diets include fat from 3 to $6 \%$ as a maximum level (161). Digestibility of fat from sow's milk in suckling pigs is over 90\%; however, digestibility of fat from solid feed in newly weaned pigs is as low as $73 \%(162,163)$ and increases gradually return to the preweaning level ranging from 4 to 6 weeks post-weaning $(23,164)$. The form of the milk fat presents as micelles and consequently aid digestion (165) by pancreatic lipase, whereas fat in solid diets is not in an easily accessible form. The synthesis of hepatic bile acid is low at weaning in pigs (166). Therefore, the emulsification process is a rate-limiting step in the digestion of dietary fat during this period.

\section{Lysophospholipids}

Phospholipids, nature's principal surface-active agents, performs as an excellent emulsifying agent. The main constituents of the phospholipid mixture are phosphatidylcholine, phosphatidylinositol, phosphatidylethanolamine, and phosphatidic acid (167). The majority of the phospholipid in the small intestine is derived from bile with a smaller component coming from the diet. Phospholipase A2, a pancreatic enzyme secreted in bile, hydrolyzes the ester bond at the sn-2 position of the phospholipid, yielding a free fatty acid and lysophospholipids with a different head group, which are then incorporated into micelles for subsequent absorption (168-170). On a commercial scale, lysophospholipids are often produced by the modification of soybean phospholipids (chemical or enzymatic methods) using phospholipase A2 which yields a mixture of lysophospholipids with different head groups depending on the source of the phospholipids (e.g., lysophosphatidylcholine, lysophosphatidylinositol, lysophosphatidylethanolamine, and lysophosphatidic acid) (170, 171). Hydrophilic-lipophilic balance (HLB) values are assigned to emulsifiers from 0 to 20 , and higher values are assigned to those are more hydrophilic. Soybean lysophospholipids have an HLB value of 19 (172), whereas the native soybean phospholipids have values of 5 (173). In addition, lysophospholipids have been reported to involve in various biological processes such as cell growth, proliferation and differentiation mediated by specific G-protein coupled receptors (174-176). Lysophospholipids supplemented in the diet showed to increase crypt cell mitosis and enhance villus morphology in broiler chickens (177). Lysophospholipids involve in epithelial cell restitution via cytoskeletal remodeling with activation of actin filament redistribution and stress fiber formation (178). It showed to reduce mucosal damage and inflammation by increasing epithelial cell restitution when induced colitis in rats (179). In broiler chickens, lysophospholipids increased crypt cell mitosis (180), and enhanced villus morphology (177).

\section{Prebiotics}

One of the most frequently employed product is prebiotics (181). Prebiotics has been widely used for improving beneficial microbial populations in the intestines. The definition of prebiotics was first introduced by Gibson and Roberfroid (182) as "Non-digestible food ingredient that beneficially affects the host by selectively stimulating the growth and/or activity of one or a limited number of bacteria in the colon, and thus improves host health." This concept has been refined during the past 20 years, and the definition to date was defined by Bindels et al. (183) as "a prebiotic is a non-digestible compound that, through its metabolization by microorganisms in the gut, modulates composition and/or activity of the gut microbiota, thus conferring a beneficial physiological effect on the host." Bindels et al. (183) indicated the metabolic benefits attributed to prebiotics do not require a selective fermentation, which was mentioned in the earlier concept. The revised definition instead focused on the concept of ecological and functional characteristics of the microbiota to be relevant for host physiology, such as ecosystem diversity, and the support of broad microbial consortia. Many studies focusing on prebiotics such as inulin, fructooligosaccharides, galactooligosaccharides, and mannanoligosaccharides, proved the link between prebiotics consumption and restoring intestinal balance (184-187). Additionally, regardless of bacterial fermentation, prebiotic oligosaccharides (such as fructooligosaccharides and galactooligosaccharides) were shown to exert an anti-inflammatory effect or have an anti-adhesive activity to inhibit binding pathogens (188, 189). Studies with fructooligosaccharides showed that supplementing with fructooligosaccharides caused a shift in intestinal microbial composition via modulating short-chain fatty acids production, which provides substrates and promotes normal proliferation and differentiation of intestinal cells $(190,191)$.

\section{Fermented Rice Bran Extracts}

Rice bran, a co-product obtained during rice milling process, is rich in cell wall materials such as hemicellulose and cellulose containing neutral detergent fiber in the range of 19-34\% (192, 193). The high fiber content is a major limitation of its use in young animal diets especially in newly weaned pigs. Defatting, fermentation, and enzymatic treatment (193-195) have been applied to improve the nutritional value of rice bran. Prebiotic properties of rice bran were reported in studies with mice (196) and pigs (94). Glucooligosaccharides, one of the emerging prebiotics was shown to be assimilated by Bifidobacterium species, but not by pathogenic species including Clostridium and Salmonella (197). Rice bran oligosaccharides, mainly composed of glucooligosaccharides, was reported to possess prebiotic potential $(193,198)$. The rice bran glucooligosaccharides was 
shown to be able to promote the growth of Lactobacillus species, which was not hydrolyzed by human intestinal conditions.

\section{Probiotics}

Probiotics is defined as "living microorganisms that, on ingestion in sufficient numbers, exert health benefits beyond basic nutrition" (199). Prebiotics and probiotics exert their beneficial effects in a similar manner, through the modulations in the intestinal microbiota. Probiotics affect the microbiota via beneficial microorganisms, whereas prebiotics alter the microbiota by the supply of a substrate. Cultures commonly used in feed are lactic acid bacteria, Bacillus and yeasts (200). The beneficial microbes play an important role in maintaining the host health. They reduce the colonization and invasion of pathogens, maintain epithelial integrity, and enhance immune function $(201,202)$. Probiotics used in pig diets showed beneficial effects including reduced diarrhea incidence and improved in growth performance $(13,203)$. The combinational use of prebiotics and probiotics as synbiotics beneficially affects the microenvironment of the intestines to improve the survival and colonization of live beneficial microorganisms in the GIT (204-206).

\section{Postbiotics}

Postbiotics is relatively new term in animal science and collectively refers to bioactive compounds produced by probiotic microorganisms during a fermentation process (207, 208). Postbiotics, in fact, has been used in animal production in different terms including bacterial extracts and yeast culture. Postbiotics often includes microbial cell contents and cell wall. Fermentation products of Saccharomyces cerevisiae, also called yeast culture, have long been used in animal feeds to enhance appetite of lactating animals $(104,209-211)$, but more recently to enhance intestinal health of nursery pigs by bioactive compounds in fermentation products $(212,213)$. Yeast culture includes residual yeast cell wall fragments, and various products from yeast fermentation such as organic acids, nucleotides, vitamins, and amino acids (104). Yeast cell wall fragments have also used as postbiotics to modulate intestinal immune status and health $(2,126,214)$. Selected bioactive compounds in postbiotics are proposed to alter microbiota composition (215). Selected postbiotics could also be investigated for their synergistic benefits with the use of probiotics.

\section{Feed Enzymes}

The major goal of the use of feed enzymes is to eliminate anti-nutritional factors to better utilize nutrients in the feed (200, 216). Carbohydrase has been widely used for their roles in breaking down non-starch polysaccharides (NSP) present in most vegetable ingredients $(217,218)$. The use of NSP enzymes showed to improve the growth performance of nursery pigs by enhancing intestinal health, nutrient digestibility (192, 194, 195). Chen et al. (102) evaluated supplemental effects of xylanase fed to nursery pigs with or without $30 \%$ corn distillers' dried grains with solubles (DDGS) as a source of NSP. The supplementation of 30\% DDGS increased digesta viscosity, reduced the digestibility of dry matter and gross energy, and increased intestinal inflammation, whereas the supplementation of xylanase alleviated the negative effects on growth performance by feeding high-level DDGS by reducing digesta viscosity, improving nutrient digestibility, and reducing inflammatory response. In addition, xylo-oligosaccharides generated in the small intestine from xylans by xylanase hydrolysis could be potential prebiotics for lactogenic bacteria which warrants further research.

Protease breaks down peptide bonds in protein and polypeptides. Specific protease can target allergenic proteins in legume seed meals, such as glycinin and $\beta$-conglycinin causing gut inflammation, diarrhea and growth reduction (108). Duarte et al. (103) and Chen et al. (219) showed supplemental protease reduced gut inflammation and improvement protein digestibility and feed efficiency in nursery pigs. Phytase catalyzes the phytate hydrolysis and releases phosphorous and phytatebound nutrients (220). The use of phytase increased phosphorus digestibility, bone characteristics, and growth performance $(105,221)$. More recently elevated dose of phytase so called superdosing of phytase (often more than 10-folds of typical dose levels) has received attention and applied in pig production. It is hypothesized that typical supplementation level of phytase would not completely hydrolyze phytate in the stomach and superdosing of phytase would provide opportunities of complete hydrolysis of phytate in the stomach. Complete hydrolysis of phytate not only provides available phosphates along with release of other essential minerals but also free inositol for their potential function in insulin sensitivity and carbohydrate metabolism.

\section{Nucleotides}

Nucleotides are bioactive molecules that play important roles in metabolic, structural and regulatory functions (222). The milk of sow contain large concentration of nucleotides during 28-day lactation (223) that supplies the needs of the piglets. At weaning, the requirement of nucleotides increases for immune response and the intestinal recovery, whereas the endogenous synthesis is insufficient to meet the requirements $(224,225)$ and the weaning diet has low concentration compared with milk (226). Therefore, exogenous sources of nucleotides can be used to supply this demand and alleviate the effects of the weaning stress $(110,111,223,226)$. Sauer et al. (226) reported that dietary nucleotides positively affect the intestinal morphology, the immune response, the hepatic function and the microbiota. The consumption of nucleotides can improve the feed efficiency of nursery pigs by reducing the immune response and the oxidative stress status, whereas increasing the villus height and the energy digestibility $(110,111)$. The effect of dietary nucleotide on modulating the immune system and the microbiota suggested that it can be used to prevent post-weaning diarrhea in pigs as confirmed by Wiseman (225). According to Li et al. (112) dietary nucleotides can reduce diarrhea caused by enterotoxigenic $E$. coli by modulating the microbiota and enhancing the immune response of weaning pigs. Some of unsolved questions include the types and profiles of nucleotides for the effectiveness. Commercially available nucleotide supplements are typically obtained from yeast extracts providing combination of adenosine-5-monophosphate 
(AMP), cytidine-5-monophosphate (CMP), guanosine-5monophosphate (GMP), and uridine-5-monophosphate (UMP). Some others source nucleotides from bacterial fermentation extensively including inosine-5-monophosphate (IMP). Ideal ratio among nucleotides and functional uniqueness of IMP warrant future investigations.

\section{Organic Acids and Acidifiers}

Organic acids have been used in the pig diets to decrease gastric pH (227), prevent pathogenic bacterial growth (228), improve nutrient digestion (229), and improve growth performance (230). Gastric $\mathrm{pH}$ in weaned pigs ranges between 2.6 and 5.0 , whereas the optimum gastric $\mathrm{pH}$ for vegetable protein digestion is in the range of 2.0-3.5. Inclusion of organic acids such as fumaric and citric acids are shown to have beneficial effects in newly weaned pigs $(231,232)$. Organic acids can modulate the intestinal microbiota by inhibiting the $\mathrm{pH}$ sensitive microbial without affecting the lactic acid bacteria (233, 234). According to Ren et al. (235) $1 \%$ formic and propionic acid mixture can reduce the inflammatory response of weaning pigs challenged with enterotoxigenic E. coli. Current challenges with organic acids, however, are their effectiveness affecting luminal $\mathrm{pH}$ at a realistic supplementation level without affecting appetite or feed intake of nursery pigs. Recent advances to overcome these challenges include encapsulation or coating technologies.

\section{Phytobiotics and Phytogenic Feed Additives}

The major biological functions of phytogenic feed additives (PFA) include improve feed palatability, stimulation of digestive enzyme secretions, microbiota modulation, antimicrobial, antiinflammatory, and antioxidant activity $(116,117,119,236,237)$. The PFA are reported to improve piglets' post-weaning feed intake and growth performance when added into sow diets. A mixture of phytogenic compounds (anethol, cinnamaldehyde, and eugenol) used as feed additive for sows during late gestation and lactation showed to increase post-weaning feed intake and growth rate of piglets (117). The three compounds were detected in amniotic fluid and the positive effects on post-weaning performance were attributed to the maternal exposure to the flavor of the phytogenic compounds. $\mathrm{Li}$ et al. (118) evaluated the effects of essential oil (a mixture of thymol and cinnamaldehyde) supplemented in feeds for nursery pigs with or without antibiotic growth promotors. The supplementation of thymol and cinnamaldehyde increased growth of pigs during 35-day post-weaning period, and the effect was similar to feeding antibiotics. In the same study, improved dry matter and crude protein digestibility were detected by the essential oil supplementation. Similar beneficial effects of PFA on nutrient digestibility in s nursery pigs were reported in other studies (120). The potential mechanisms of improving nutrient digestibility may be partially due to the stimulation of digestive enzymes activities and stimulation of bile secretion by phytogenic compounds (238). Beneficial effects on intestinal morphological changes may provide further information on promoting growth performance; however, the results obtained from different studies have not been consistent (239) where PFA reduced feed intake possibly due to strong aroma from oregano extracts. Commercial products often mask the aroma from PFA by encapsulation or coating which are practical for the feed application of PFA.

\section{Immunoglobulin-Containing Compounds}

Under the commercial production systems, pigs are usually weaned at 3-4 weeks of age, whereas this is early stage of their life when the ability of pigs to produce immunoglobulins is not fully developed (55). The addition of immunoglobulinscontaining compounds in the post-weaning diets may be beneficial. Immunoglobulin-rich product, blood plasma, has been shown to have beneficial effects on increasing postweaning feed intake and growth rate, and reducing post-weaning diarrhea $(121,122,240)$. Furthermore, in disease challenge studies with E. coli, blood plasma is reported to maintain intestinal barrier function, increase antibody production, and decrease pro-inflammatory cytokine expression $(241,242)$. In addition, supplementation of blood plasma is reported to alleviate negative impact on growth performance by feeding mycotoxin contaminated feed (10). However, despite its high nutritional value, the availability of amino acid (especially lysine) can be reduced with excessive heating treatment during manufacturing process of blood plasma (240). Additionally, increasing biosecurity concerns using blood plasma has limited its application in swine diets $(24,25)$.

\section{Mycotoxin Deactivators}

Among the mycotoxins identified ( 300-400), aflatoxins, fumonisins, ochratoxin A, trichothecenes such as deoxynivalenol $(\mathrm{DON})$, and zearalenone are some of the mycotoxins that can significantly affect animals' health $(27,243)$. Impact of major mycotoxins on nursery pigs are summarized in Table 4. Previous studies have shown that young pigs are especially susceptible to trichothecenes (especially DON), and fumonisins due to their negative effects on intestines $(252,253)$. Consumption of DONcontaminated feed can decrease feed intake, impair intestinal barrier function, and increase intestinal inflammatory response in pigs $(123,254-256)$. Exposure to DON causes epithelial injuries and compromise barrier function by decreasing tight junction proteins expression and can modulate immune response by increasing the susceptibility to enteric infections (257259). Commonly used methods include adsorbents (binding agents), enzymatic or microbial detoxification, purified enzymes, and/or "bio-protection" method using substances such as plant ingredients. Absorbents can absorb certain mycotoxins such as aflatoxin, but it does not work at the same extent to other mycotoxins. Murugesan et al. (27), in a study comparing the adsorption capacity of different commercially available mycotoxin binder products, showed that tested products have poor adsorption for DON. Alternative strategies such as enzymatic or microbial detoxification, where mycotoxins are catabolized or cleaved to less or non-toxic compounds are much more effective compared to using binding agents (27, 260). Holanda and Kim (123) reported that yeast-based detoxifiers with functional components can improve detoxifying 
TABLE 4 | Impact of mycotoxins on nursery pigs and regulatory limit of major mycotoxins.

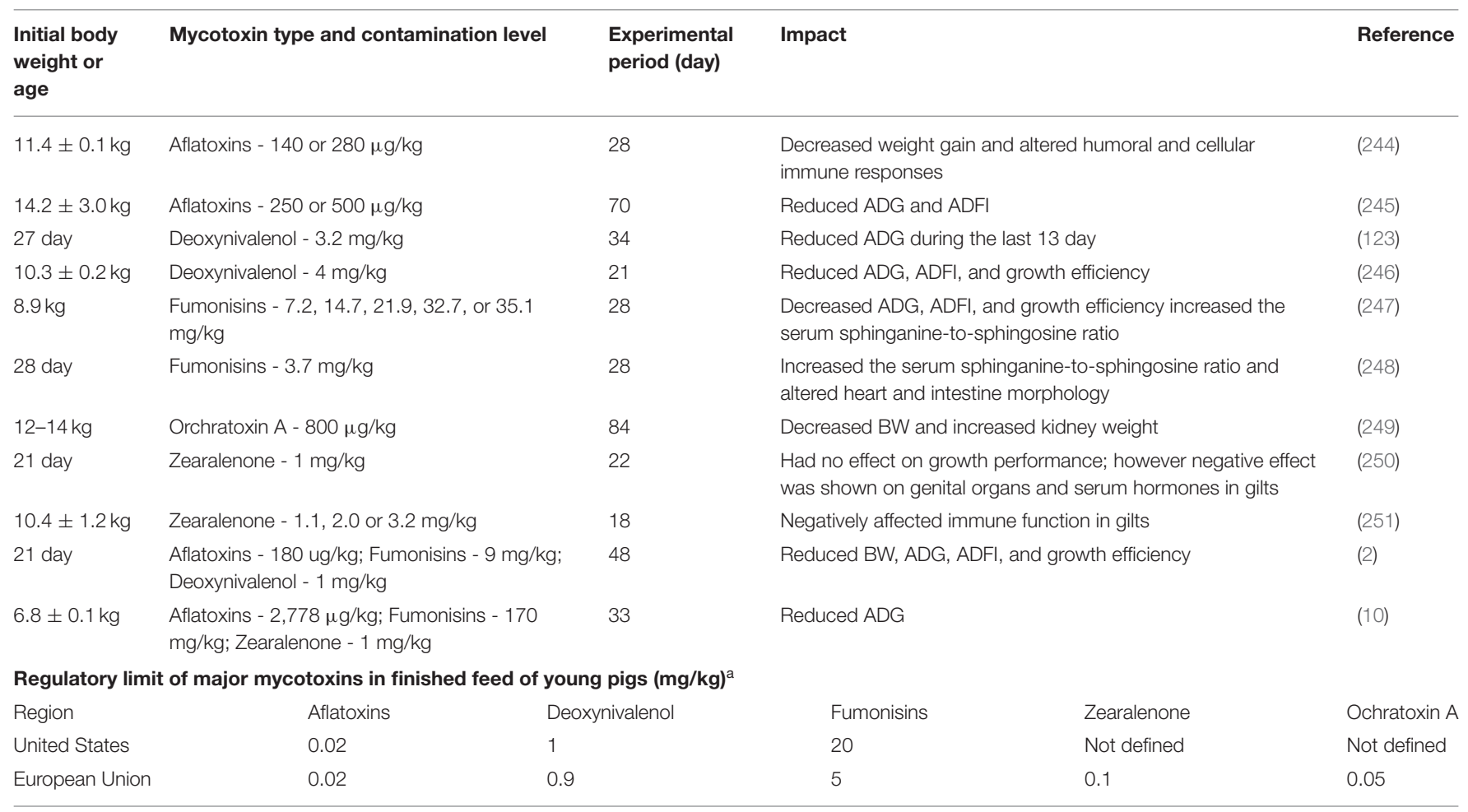

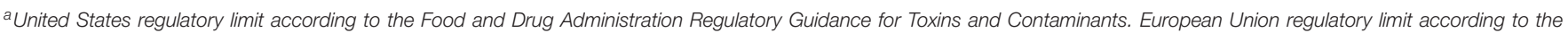
European Commission Directive 2003/100/EC and the European Commission Recommendation 2006/576/EC.

properties in newly-weaned pigs fed DON contaminated feed $(3.2 \mathrm{mg} / \mathrm{kg})$, potentially by increasing adsorption capacity, improving immune function, and enhancing intestinal health. Fumonisins disrupt the synthesis of sphingolipids-containing cell membrane because they have a chemical structure that is similar to that of the sphingoid bases deoxysphinganine (261), key enzymes involved in sphingolipid biosynthesis (262). This dysregulation of sphingolipid biosynthesis causes accumulation of the sphingoid bases (sphinganine and sphingosine), and their metabolites $(261,263)$. Negative impact of fumonisins include porcine pulmonary edema, damages to gastrointestinal structure, and reduction in growth performance $(254,264,265)$. In a study evaluated effects of different commercial products on mitigating fumonisins negative effects during nursery phase showed a bentonite and yeast-based product alleviated negative impact of fumonisin $(50-60 \mathrm{mg} / \mathrm{kg})$ on growth performance (124). Different regulations on maximum levels of mycotoxins for young pigs have been established by different countries; however, previous studies have shown that the contamination levels below the regulatory limits showed negative effects on growth performance and immune function (see Table 4). Furthermore, information on the regulatory limits on some of the major mycotoxins (i.e., zearalenone and ochratoxin A) and co-contamination of multiple mycotoxins are not available. The co-contamination with multiple mycotoxins in feed can cause more adverse effects than a single mycotoxin due to the additive or synergistic interaction (266). Additionally, limited practice on mitigating chronic exposure to lowdose mycotoxins may negatively impact production efficiency. Understanding the prevalence of mycotoxins in the feed and applying effective interventions are critical to ensure young pigs' health.

\section{CONCLUSIONS}

At weaning, pigs deal with multiple stressors such as separation from the sow, a new environment, separation from littermates and cohabitation with new pigs, and the abrupt change of diet types from liquid sow milk to solid feeds. Weaning causes morphological and functional changes of the small intestine of pigs where most of the nutrients are being digested and absorbed. These changes can result in severe diarrhea and even cause mortality. In addition, due to the increasing feed safety concerns, volatile price of specialty feedstuffs, and regulatory changes on using certain feed additives (i.e., antibiotics and zinc oxide), some of the commonly used feedstuffs and additives in the nursery diets have been limited for their use. Alternative nutritional strategies aligning with these changes have been tried to combat the weaning challenges.

In order to minimize weaning-associated depressed growth, the need for developing effective nutritional strategies is critical. Functional feed additives that have a positive influence on enhancing intestinal health will aid in amelioration of the depressed growth and intestinal dysfunction associated 
with weaning stress. The functional feed additives such as protein hydrolysates, emulsifiers, prebiotics, probiotics, postbiotics, enzymes, nucleotides, organic acids, phytogenic feed additives, immunoglobulin-containing compounds, and mycotoxin deactivators were evaluated their roles in promoting intestinal health and growth of nursery pigs to allow better nutritional management during the crucial post-weaning period. The evaluations on how these feed additives affect the intestinal architectural structure, intestinal barrier function, mucosal

\section{REFERENCES}

1. Lallès J-P, Boudry G, Favier C, Le Floc'h N, Luron I, Montagne L, et al. Gut function and dysfunction in young pigs: physiology. Anim Res. (2004) 53:301-16. doi: 10.1051/animres:2004018

2. Kim SW, Débora Muratori Holanda, Gao X, Park I, Yiannikouris A. Efficacy of a yeast cell wall extract to mitigate the effect of naturally cooccurring mycotoxins contaminating feed ingredients fed to young pigs: impact on gut health, microbiome, and growth. Toxins. (2019) 11:633. doi: 10.3390/toxins11110633

3. Shen Y Bin, Voilqué G, Odle J, Kim SW. Dietary L-tryptophan supplementation with reduced large neutral amino acids enhances feed efficiency and decreases stress hormone secretion in nursery pigs under social-mixing stress. J Nutr. (2012) 142:1540-6. doi: 10.3945/jn.112.163824

4. Heo JM, Opapeju FO, Pluske JR, Kim JC, Hampson DJ, Nyachoti CM. Gastrointestinal health and function in weaned pigs: a review of feeding strategies to control post-weaning diarrhoea without using in-feed antimicrobial compounds. J Anim Physiol Anim Nutr. (2013) 97:207-37. doi: 10.1111/j.1439-0396.2012.01284.x

5. Hampson DJ. Alterations in piglet small intestinal structure at weaning. Res Vet Sci. (1986) 40:32-40. doi: 10.1016/S0034-5288(18)30482-X

6. Jensen P. Observations on the maternal behaviour of freeranging domestic pigs. Appl Anim Behav Sci. (1986) 16:131-42. doi: 10.1016/0168-1591(86)90105-X

7. Kim SW. Sow milk. In: Park YW, Haenlein GFW, editors. Milk Dairy Products in Human Nutrition. Oxford: John Wiley \& Sons (2013). p. 614-26. doi: 10.1002/9781118534168.ch28

8. Kim SW. Meeting amino acid requirements in pig nutrition. In: Wiseman J, editor. Achieving Sustainable Production of Pig Meat. London: Burleigh Dodds Science Publishing (2018). p. 145-65. doi: 10.1201/9781351114349

9. Pluske JR, Hampson DJ, Williams IH. Factors influencing the structure and function of the small intestine in the weaned pig: a review. Livest Prod Sci. (1997) 51:215-36. doi: 10.1016/S0301-6226(97)00057-2

10. Weaver AC, Kim SW, Campbell JM, Crenshaw JD, Polo J. Efficacy of dietary spray dried plasma protein to mitigate the negative effects on performance of pigs fed diets with corn naturally contaminated with multiple mycotoxins. $J$ Anim Sci. (2014) 92:3878-86. doi: 10.2527/jas.2013-6939

11. McCracken BA, Spurlock ME, Roos MA, Zuckermann FA, Gaskins HR. Weaning anorexia may contribute to local inflammation in the piglet small intestine. J Nutr. (1999) 129:613-9. doi: 10.1093/jn/129.3.613

12. Spreeuwenberg MAM, Verdonk JMAJ, Gaskins HR, Verstegen MWA. Small Intestine epithelial barrier function is compromised in pigs with low feed intake at weaning. J Nutr. (2001) 131:1520-7. doi: 10.1093/jn/131.5.1520

13. Lallès JP, Bosi P, Smidt $H$, Stokes CR. Nutritional management of gut health in pigs around weaning. Proc Nutr Soc. (2007) 66:260-8. doi: 10.1017/S0029665107005484

14. Niu Q, Li P, Hao S, Zhang Y, Kim SW, Li H, et al. Dynamic distribution of the gut microbiota and the relationship with apparent crude fiber digestibility and growth stages in pigs. Sci Rep. (2015) 5:1-7. doi: 10.1038/srep09938

15. Gresse R, Chaucheyras-Durand F, Fleury MA, Van de Wiele T, Forano E, Blanquet-Diot S. Gut microbiota dysbiosis in postweaning piglets: understanding the keys to health. Trends Microbiol. (2017) 25:851-73. doi: 10.1016/j.tim.2017.05.004 immunity, and intestinal microbial community can provide valuable information to formulate optimized nursery diets. Combinational uses of these feed additives as synbiotics, could provide further benefits to nursery pigs.

\section{AUTHOR CONTRIBUTIONS}

All authors listed have made a substantial, direct and intellectual contribution to the work, and approved it for publication.

16. Adhikari B, Kim SW, Kwon YM. Characterization of microbiota associated with digesta and mucosa in different regions of gastrointestinal tract of nursery pigs. Int J Mol Sci. (2019) 20:9-12. doi: 10.3390/ijms20071630

17. Eisemann J, Kim SW. Animal Nutrition. 1st ed. Dubuque, IA: Kendall Hunt Publishing (2014)

18. Peterson LW, Artis D. Intestinal epithelial cells: regulators of barrier function and immune homeostasis. Nat Rev Immunol. (2014) 14:141-53. doi: $10.1038 /$ nri3608

19. Holzer-Petsche U, Petritsch W, Hinterleitner T, Eherer A, Sperk G, Krejs GJ. Effect of neuropeptide Y on jejunal water and ion transport in humans. Gastroenterology. (1991) 101:325-30. doi: 10.1016/0016-5085(91)90007-8

20. Umar S. Intestinal stem cells. Curr Gastroenterol Rep. (2010) 12:340-8. doi: 10.1007/s11894-010-0130-3

21. Cheng H, Leblond CP. Origin, differentiation and renewal of the four main epithelial cell types in the mouse small intestine I. Columnar cell. Am J Anat. (1974) 141:461-79. doi: 10.1002/aja.1001410403

22. Wong WM, Wright NA. Cell proliferation in gastrointestinal mucosa. J Clin Pathol. (1999) 52:321-33. doi: 10.1136/jcp.52.5.321

23. Cera KR, Mahan DC, Cross RF, Reinhart GA, Whitmoyer RE. Effect of age, weaning and postweaning diet on small intestinal growth and jejunal morphology in young swine. J Anim Sci. (1988) 66:574. doi: $10.2527 /$ jas $1988.662574 \mathrm{x}$

24. Pasick J, Berhane Y, Ojkic D, Maxie G, Embury-Hyatt C, Swekla K, et al. Investigation into the role of potentially contaminated feed as a source of the first-detected outbreaks of porcine epidemic diarrhea in Canada. Transbound Emerg Dis. (2014) 61:397-410. doi: 10.1111/tbed. 12269

25. Aubry P, Thompson JL, Pasma T, Furness MC, Tataryn J. Weight of the evidence linking feed to an outbreak of porcine epidemic diarrhea in Canadian swine herds. J Swine Heal Prod. (2017) 25:69-72. Available online at: https://www.aasv.org/library/swineinfo/item.php?SHAP/2017/v25n2p69. pdf

26. Hedemann MS, Højsgaard S, Jensen BB. Small intestinal morphology and activity of intestinal peptidases in piglets around weaning. J Anim Physiol Anim Nutr. (2003) 87:32-41. doi: 10.1046/j.1439-0396.2003.00405.x

27. Murugesan GR, Ledoux DR, Naehrer K, Berthiller F, Applegate TJ, Grenier $\mathrm{B}$, et al. Prevalence and effects of mycotoxins on poultry health and performance, and recent development in mycotoxin counteracting strategies. Poult Sci. (2015) 94:1298-315. doi: 10.3382/ps/pev075

28. Moeser AJ, Klok C Vander, Ryan KA, Wooten JG, Little D, Cook VL, et al. Stress signaling pathways activated by weaning mediate intestinal dysfunction in the pig. Am J Physiol - Gastrointest Liver Physiol. (2007) 292:173-81. doi: 10.1152/ajpgi.00197.2006

29. Moeser AJ, Pohl CS, Rajput M. Weaning stress and gastrointestinal barrier development: Implications for lifelong gut health in pigs. Anim Nutr. (2017) 3:313-21. doi: 10.1016/j.aninu.2017.06.003

30. Hampson DJ, Kidder DE. Influence of creep feeding and weaning on brush border enzyme activities in the piglet small intestine. Res Vet Sci. (1986) 40:24-31. doi: 10.1016/s0034-5288(18)30481-8

31. Tsukahara T, Kishino E, Inoue R, Nakanishi N, Nakayama K, Ito T, et al. Correlation between villous height and the disaccharidase activity in the small intestine of piglets from nursing to growing. Anim Sci J. (2013) 84:54-9. doi: 10.1111/j.1740-0929.2012.01039.x 
32. Ulluwishewa D, Anderson RC, McNabb WC, Moughan PJ, Wells JM, Roy NC. Regulation of tight junction permeability by intestinal bacteria and dietary components. J Nutr. (2011) 141:769-76. doi: 10.3945/jn.110.135657

33. Hartsock A, Nelson WJ. Adherens and tight junctions: structure, function and connections to the actin cytoskeleton. Biochim Biophys Acta-Biomembr. (2008) 1778:660-9. doi: 10.1016/j.bbamem.2007.07.012

34. McKay DM, Baird AW. Cytokine regulation of epithelial permeability and ion transport. Gut. (1999) 44:283-9. doi: 10.1136/gut.44.2.283

35. Kunzelmann K, Mall M. Electrolyte transport in the mammalian colon: mechanisms and implications for disease. Physiol Rev. (2002) 82:245-89. doi: 10.1152/physrev.00026.2001

36. Blikslager AT, Moeser AJ, Gookin JL, Jones SL, Odle J. Restoration of barrier function in injured intestinal mucosa. Physiol Rev. (2007) 87:545-64. doi: 10.1152/physrev.00012.2006

37. Bröer S. Amino acid transport across mammalian intestinal and renal epithelia. Physiol Rev. (2008) 88:249-86. doi: 10.1152/physrev.00018.2006

38. Asmar R El, Panigrahi P, Bamford P, Berti I, Not T, Coppa G V., et al. Hostdependent zonulin secretion causes the impairment of the small intestine barrier function after bacterial exposure. Gastroenterology. (2002) 123:160715. doi: 10.1053/gast.2002.36578

39. Arrieta MC, Bistritz L, Meddings JB. Alterations in intestinal permeability. Gut. (2006) 55:1512-20. doi: 10.1136/gut.2005.085373

40. Mullin JM, Valenzano MC, Verrecchio JJ, Kothari R. Age- and diet-related increase in transepithelial colon permeability of Fischer 344 rats. Dig Dis Sci. (2002) 47:2262-70. doi: 10.1023/A:1020191412285

41. Sander GR, Cummins AG, Powell BC. Rapid disruption of intestinal barrier function by gliadin involves altered expression of apical junctional proteins. FEBS Lett. (2005) 579:4851-5. doi: 10.1016/j.febslet.2005.07.066

42. Pié S, Lallès JP, Blazy F, Laffitte J, Sève B, Oswald IP. Weaning is associated with an upregulation of expression of inflammatory cytokines in the intestine of piglets. J Nutr. (2004) 134:641-7. doi: 10.1093/jn/134.3.641

43. Wijtten PJA, Meulen J Van Der, Verstegen MWA. Intestinal barrier function and absorption in pigs after weaning: a review. Br J Nutr. (2011) 105:967-81. doi: 10.1017/S0007114510005660

44. Xun W, Shi L, Zhou H, Hou G, Cao T. Effect of weaning age on intestinal mucosal morphology, permeability, gene expression of tight junction proteins, cytokines and secretory IgA in Wuzhishan mini piglets. Ital J Anim Sci. (2018) 17:976-83. doi: 10.1080/1828051X.2018.1426397

45. McLamb BL, Gibson AJ, Overman EL, Stahl C, Moeser AJ. Early weaning stress in pigs impairs innate mucosal immune responses to enterotoxigenic E. coli challenge and exacerbates intestinal injury and clinical disease. PLoS ONE. (2013) 8:e59838. doi: 10.1371/journal.pone.0059838

46. Smith F, Clark JE, Overman BL, Tozel CC, Huang JH, Rivier JEF, et al. Early weaning stress impairs development of mucosal barrier function in the porcine intestine. Am J Physiol - Gastrointest Liver Physiol. (2010) 298:352-63. doi: 10.1152/ajpgi.00081.2009

47. Van Der Meulen J, Koopmans SJ, Dekker RA, Hoogendoorn A. Increasing weaning age of piglets from 4 to 7 weeks reduces stress, increases postweaning feed intake but does not improve intestinal functionality. Animal. (2010) 4:1653-61. doi: 10.1017/S1751731110001011

48. Massacci FR, Berri M, Lemonnier G, Guettier E, Blanc F, Jardet D, et al. Late weaning is associated with increased microbial diversity and Faecalibacterium prausnitzii abundance in the fecal microbiota of piglets. Anim Microbiome. (2020) 2:1-12. doi: 10.1186/s42523-020-0020-4

49. Castro GA, Arntzen CJ. Immunophysiology of the gut: a research frontier for integrative studies of the common mucosal immune system. Am J Physiol Liver Physiol. (1993) 265:G599-610. doi: 10.1152/ajpgi.1993.265.4.G599

50. Furness JB, Kunze WAA, Clerc N. Nutrient tasting and signaling mechanisms in the gut II. The intestine as a sensory organ: neural, endocrine, and immune responses. Am J Physiol Liver Physiol. (1999) 277:G922-8. doi: 10.1152/ajpgi.1999.277.5.G922

51. Neutra MR, Mantis NJ, Kraehenbuhl JP. Collaboration of epithelial cells with organized mucosal lymphoid tissues. Nat Immunol. (2001) 2:1004-9. doi: 10.1038/ni1101-1004

52. Mabbott NA, Donaldson DS, Ohno H, Williams IR, Mahajan A. Microfold (M) cells: important immunosurveillance posts in the intestinal epithelium. Mucosal Immunol. (2013) 6:666-77. doi: 10.1038/mi. 2013.30
53. Artis D. Epithelial-cell recognition of commensal bacteria and maintenance of immune homeostasis in the gut. Nat Rev Immunol. (2008) 8:411-20. doi: $10.1038 /$ nri2316

54. Brandtzaeg P. Induction of secretory immunity and memory at mucosal surfaces. Vaccine. (2007) 25:5467-84. doi: 10.1016/j.vaccine.2006.12.001

55. Stokes CR, Bailey M, Haverson K, Harris C, Jones P, Inman C, et al. Postnatal development of intestinal immune system in piglets: implications for the process of weaning. Anim Res. (2004) 53:325-34. doi: 10.1051/animres:2004020

56. Gallois M, Rothkötter HJ, Bailey M, Stokes CR, Oswald IP. Natural alternatives to in-feed antibiotics in pig production: can immunomodulators play a role? Animal. (2009) 3:1644-61. doi: 10.1017/S1751731109004236

57. Sido A, Radhakrishnan S, Kim SW, Eriksson E, Shen F, Li Q, et al. A food-based approach that targets interleukin-6, a key regulator of chronic intestinal inflammation and colon carcinogenesis. J Nutr Biochem. (2017) 43:11-7. doi: 10.1016/j.jnutbio.2017.01.012

58. Capaldo CT, Nusrat A. Cytokine regulation of tight junctions. Biochim Biophys Acta - Biomembr. (2009) 1788:864-71. doi: 10.1016/j.bbamem.2008.08.027

59. Al-Sadi R, Boivin M, Ma T. Mechanism of cytokine modulation of epithelial tight junction barrier. Front Biosci. (2009) 14:2765-78. doi: 10.2741/3413

60. Wang J, Chen L, Li P, Li X, Zhou H, Wang F, et al. Gene expression is altered in piglet small intestine by weaning and dietary glutamine supplementation. J Nutr. (2008) 138:1025-32. doi: 10.1093/jn/138.6.1025

61. Vergauwen H, Tambuyzer B, Jennes K, Degroote J, Wang W, De Smet S, et al. Trolox and ascorbic acid reduce direct and indirect oxidative stress in the IPEC-J2 cells, an in vitro model for the porcine gastrointestinal tract. PLoS ONE. (2015) 10:e0120485. doi: 10.1371/journal.pone.0120485

62. Rao R. Oxidative stress-induced disruption of epithelial and endothelial tight junctions. Front Biosci. (2008) 13:7210-26. doi: 10.2741/3223

63. Rosero DS, Odle J, Moeser AJ, Boyd RD, Van Heugten E. Peroxidised dietary lipids impair intestinal function and morphology of the small intestine villi of nursery pigs in a dose-dependent manner. Br J Nutr. (2015) 114:1985-92. doi: 10.1017/S000711451500392X

64. Kelly J, Daly K, Moran AW, Ryan S, Bravo D, Shirazi-Beechey SP. Composition and diversity of mucosa-associated microbiota along the entire length of the pig gastrointestinal tract; dietary influences. Environ Microbiol. (2017) 19:1425-38. doi: 10.1111/1462-2920.13619

65. Levesque CL, Hooda S, Swanson KS, De Lange K. Alterations in ileal mucosa bacteria related to diet complexity and growth performance in young pigs. PLoS ONE. (2014) 9:e108472. doi: 10.1371/journal.pone.0108472

66. Levesque CL, Yu H, Gong J, de Lange CFM. Ileal mucosa-associatedbut not ileal digesta-bacterial profiles in grower pigs are influenced by nutrition and use of antibiotics for weaner pigs. J Anim Sci. (2012) 90:448-50. doi: $10.2527 /$ jas. 54004

67. Li P, Niu Q, Wei Q, Zhang Y, Ma X, Kim SW, et al. Microbial shifts in the porcine distal gut in response to diets supplemented with Enterococcus faecalis as alternatives to antibiotics. Sci Rep. (2017) 7:1-10. doi: $10.1038 /$ srep41395

68. Zoetendal EG, Raes J, Van Den Bogert B, Arumugam M, Booijink CC, Troost FJ, et al. The human small intestinal microbiota is driven by rapid uptake and conversion of simple carbohydrates. ISME J. (2012) 6:1415-26. doi: 10.1038/ismej.2011.212

69. Zhao W, Wang Y, Liu S, Huang J, Zhai Z, He C, et al. The dynamic distribution of porcine microbiota across different ages and gastrointestinal tract segments. PLOS ONE. (2015) 10:e117441. doi: 10.1371/journal.pone.0117441

70. Brooks LK. The Use of Bacillus-Based Direct-fed Microbials to Improve Growth Performance and Gut Health of Nursery Pigs. [dissertation]. Raleigh, NC: North Carolina State University (2017).

71. Albenberg L, Esipova T V., Judge CP, Bittinger K, Chen J, Laughlin $A$, et al. Correlation between intraluminal oxygen gradient and radial partitioning of intestinal microbiota. Gastroenterology. (2014) 147:105563.e8. doi: 10.1053/j.gastro.2014.07.020

72. Belkaid Y TH. Role of the microbiota in immunity and inflammation yasmine. Cell. (2015) 157:121-41. doi: 10.1016/j.cell.2014.03.011.Role

73. Mayer E a, Tillisch K, Gupta A. Gut/brain axis and the microbiota. J Clin Invest. (2015) 125:926-38. doi: 10.1172/JCI76304 
74. Ma N, Guo P, Zhang J, He T, Kim SW, Zhang G, et al. Nutrients mediate intestinal bacteria-mucosal immune crosstalk. Front Immunol. (2018) 9:116. doi: 10.3389/fimmu.2018.00005

75. Benveniste J, Lespinats G, Salomon J-C. Serum and secretory iga in axenic and holoxenic mice. J Immunol. (1971) 107:1656-62.

76. Rios D, Wood MB, Li J, Chassaing B, Gewirtz AT, Williams IR. Antigen sampling by intestinal $\mathrm{M}$ cells is the principal pathway initiating mucosal IgA production to commensal enteric bacteria. Mucosal Immunol. (2016) 9:907-16. doi: 10.1038/mi.2015.121

77. Macpherson AJ, Geuking MB, McCoy KD. Immune responses that adapt the intestinal mucosa to commensal intestinal bacteria. Immunology. (2005) 115:153-62. doi: 10.1111/j.1365-2567.2005.02159.x

78. Konstantinov SR, Awati AA, Williams BA, Miller BG, Jones P, Stokes CR, et al. Post-natal development of the porcine microbiota composition and activities. Environ Microbiol. (2006) 8:1191-9. doi: 10.1111/j.1462-2920.2006.01009.x

79. Alain B, Pajarillo E, Chae J-P, Balolong M, Bum Kim H, Kang D-K. Assessment of fecal bacterial diversity among healthy piglets during the weaning transition. J Gen Appl Microbiol. (2014) 60:140-6. doi: 10.2323/jgam.60.140

80. Yang Q, Huang X, Wang P, Yan Z, Sun W, Zhao S, et al. Longitudinal development of the gut microbiota in healthy and diarrheic piglets induced by age-related dietary changes. Microbiologyopen. (2019) 8:1-17. doi: $10.1002 / \mathrm{mbo} 3.923$

81. Sun J, Du L, Li XL, Zhong H, Ding Y, Liu Z, et al. Identification of the core bacteria in rectums of diarrheic and non-diarrheic piglets. Sci Rep. (2019) 9:1-10. doi: 10.1038/s41598-019-55328-y

82. Hopwood DE, Hampson DJ. Interactions between the intestinal microflora, diet diarrhoea, their influences on piglet health in the immediate post-weaning period. In: Pluske JR, Le Dividich J, Verstegen MWA, editors. Weaning the Pig: Concepts Consequences. Wageningen: Wageningen Academic Publishers (2003). p. 199-219. doi: 10.3920/978-908686-513-0

83. Kim SW, van Heugten E, Ji F, Lee CH, Mateo RD. Fermented soybean meal as a vegetable protein source for nursery pigs: I. Effects on growth performance of nursery pigs. J Anim Sci. (2010) 88:214-24. doi: 10.2527/jas.2009-1993

84. Yuan L, Chang J, Yin Q, Lu M, Di Y, Wang P, et al. Fermented soybean meal improves the growth performance, nutrient digestibility, and microbial flora in piglets. Anim Nutr. (2017) 3:19-24. doi: 10.1016/j.aninu.2016.11.003

85. Zhu J, Gao M, Zhang R, Sun Z, Wang C, Yang F, et al. Effects of soybean meal fermented by L. plantarum, B. subtilis and S. cerevisieae on growth, immune function and intestinal morphology in weaned piglets. Microb Cell Fact. (2017) 16:191. doi: 10.1186/s12934-017-0809-3

86. Roh SG, Carroll JA, Kim SW. Effects of fermented soybean meal on innate immunity-related gene expressions in nursery pigs acutely challenged with lipopolysaccharides. Anim Sci J. (2015) 86:508-16. doi: 10.1111/asj.12319

87. Yun JH, Kwon IK, Lohakare JD, Choi JY, Yong JS, Zheng J, et al. Comparative efficacy of plant and animal protein sources on the growth performance, nutrient digestibility, morphology and caecal microbiology of early-weaned pigs. Asian-Australasian J Anim Sci. (2005) 18:1285-93. doi: 10.5713/ajas.2005.1285

88. Xing JJ, van Heugten E, Li DF, Touchette KJ, Coalson JA, Odgaard RL, et al. Effects of emulsification, fat encapsulation, and pelleting on weanling pig performance and nutrient digestibility. J Anim Sci. (2004) 82:2601-9. doi: $10.2527 / 2004.8292601 x$

89. Zhao PY, Li HL, Hossain MM, Kim IH. Effect of emulsifier (lysophospholipids) on growth performance, nutrient digestibility and blood profile in weanling pigs. Anim Feed Sci Technol. (2015) 207:190-5. doi: 10.1016/j.anifeedsci.2015.06.007

90. Zheng L. Use of Functional Feed Additives to Enhance Intestinal Health and Growth of Nursery Pigs. [dissertation]. Raleigh, NC: North Carolina State University (2018).

91. Huang C, Qiao S, Li D, Piao X, Ren J. Effects of Lactobacilli on the performance, diarrhea incidence, VFA concentration and gastrointestinal microbial flora of weaning pigs. Asian-Australasian J Anim Sci. (2004) 17:401-9. doi: 10.5713/ajas.2004.401

92. Tang W, Qian Y, Yu B, Zhang T, Gao J, He J, et al. Effects of Bacillus subtilis DSM32315 supplementation and dietary crude protein level on performance, gut barrier function and microbiota profile in weaned piglets. J Anim Sci. (2019) 97:2125-38. doi: 10.1093/jas/skz090

93. Brousseau J-P, Talbot G, Beaudoin F, Lauzon K, Roy D, Lessard M. Effects of probiotics Pediococcus acidilactici strain MA18/5M and Saccharomyces cerevisiae subsp. boulardii strain SB-CNCM I-1079 on fecal and intestinal microbiota of nursing and weanling piglets. J Anim Sci. (2015) 93:5313-26. doi: 10.2527/jas.2015-9190

94. Herfel T, Jacobi S, Lin X, Van Heugten E, Fellner V, Odle J. Stabilized rice bran improves weaning pig performance via a prebiotic mechanism. J Anim Sci. (2013) 91:907-913. doi: 10.2527/jas.2012-5287

95. Jiao LF, Ke YL, Xiao K, Song ZH, Hu CH, Shi B. Effects of cellooligosaccharide on intestinal microbiota and epithelial barrier function of weanling pigs. J Anim Sci. (2015) 93:1157-64. doi: 10.2527/jas2014-8248

96. Xiao D, Wang Y, Liu G, He J, Qiu W, Hu X, et al. Effects of chitosan on intestinal inflammation in weaned pigs challenged by enterotoxigenic Escherichia coli. PLoS ONE. (2014) 9:e104192. doi: 10.1371/journal.pone.0104192

97. Liu P, Piao XS, Kim SW, Wang L, Shen YB, Lee HS, et al. Effects of chito-oligosaccharide supplementation on the growth performance, nutrient digestibility, intestinal morphology, and fecal shedding of Escherichia coli and Lactobacillus in weaning pigs. J Anim Sci. (2008) 86:2609-18. doi: 10.2527/jas.2007-0668

98. Liu P, Piao XS, Thacker PA, Zeng ZK, Li PF, Wang D, et al. Chitooligosaccharide reduces diarrhea incidence and attenuates the immune response of weaned pigs challenged with Escherichia coli K88. J Anim Sci. (2010) 88:3871-9. doi: 10.2527/jas.2009-2771

99. Krause DO, Bhandari SK, House JD, Nyachoti CM. Response of nursery pigs to a synbiotic preparation of starch and an anti-Escherichia coli K88 probiotic. Appl Environ Microbiol. (2010) 76:8192-200. doi: 10.1128/AEM.01427-10

100. Wang J, Wang S, Liu H, Zhang D, Wang Y, Ji H. Effects of oligosaccharides on the growth and stress tolerance of Lactobacillus plantarum ZLP001 in vitro, and the potential synbiotic effects of L. plantarum ZLP001 and fructooligosaccharide in post-weaning piglets. J Anim Sci. (2019) 97:4588-97. doi: $10.1093 /$ jas/skz254

101. Zhang J, Sun J, Chen X, Nie C, Zhao J, Guan W, et al. Combination of clostridium butyricum and corn bran optimized intestinal microbial fermentation using a weaned pig model. Front Microbiol. (2018) 9:1-10. doi: 10.3389/fmicb.2018.03091

102. Chen H, Zhang S, Kim SW. Effects of supplemental xylanase on health of the small intestine in nursery pigs fed diets with corn distillers' dried grains with solubles. J Anim Sci. (2020) 98:skaa185. doi: 10.1093/jas/skaa185

103. Duarte ME, Zhou FX, Dutra WM, Kim SW. Dietary supplementation of xylanase and protease on growth performance, digesta viscosity, nutrient digestibility, immune and oxidative stress status, and gut health of newly weaned pigs. Anim Nutr. (2019) 5:351-8. doi: 10.1016/j.aninu.2019.04.005

104. Shen YB, Carroll JA, Yoon I, Mateo RD, Kim SW. Effects of supplementing saccharomyces cerevisiae fermentation product in sow diets on performance of sows and nursing piglets. J Anim Sci. (2011) 89:2462-71. doi: 10.2527/jas.2010-3642

105. Kies AK, Kemme PA, Šebek LBJ, van Diepen JTM, Jongbloed AW. Effect of graded doses and a high dose of microbial phytase on the digestibility of various minerals in weaner pigs. J Anim Sci. (2006) 84:1169-75. doi: $10.2527 / 2006.8451169 \mathrm{x}$

106. Holloway CL, Dean Boyd R, Koehler D, Gould SA, Li Q, Patience JF. The impact of "super-dosing" phytase in pig diets on growth performance during the nursery and grow-out periods. Transl Anim Sci. (2019) 3:419-28. doi: 10.1093/tas/txy148

107. Zuo J, Ling B, Long L, Li T, Lahaye L, Yang C. Effect of dietary supplementation with protease on growth performance, nutrient digestibility, intestinal morphology, digestive enzymes and gene expression of weaned piglets. Anim Nutr. (2015) 1:276-82. doi: 10.1016/j.aninu.2015.10.003

108. Wang D, Piao XS, Zeng ZK, Lu T, Zhang Q, Li PF, et al. Effects of keratinase on performance, nutrient utilization, intestinal morphology, intestinal ecology and inflammatory response of weaned piglets fed diets with different levels of crude protein. Asian-Australasian J Anim Sci. (2011) 24:1718-28. doi: 10.5713/ajas.2011.11132 
109. Tactacan GB, Cho S-Y, Cho JH, Kim IH. Performance responses, nutrient digestibility, blood characteristics, and measures of gastrointestinal health in weanling pigs fed protease enzyme. Asian-Australasian J Anim Sci. (2016) 29:998-1003. doi: 10.5713/ajas.15.0886

110. Jang K, Kim SW. Supplemental effects of dietary nucleotides on intestinal health and growth performance of newly weaned pigs. J Anim Sci. (2019) 96:157-8. doi: 10.1093/jas/skz334

111. Weaver AC, Kim SW. Supplemental nucleotides high in inosine $5^{\prime}$ monophosphate to improve the growth and health of nursery pigs. J Anim Sci. (2014) 92:645-51. doi: 10.2527/jas.2013-6564

112. Li H, Zhao P, Lei Y, Li T, Kim I. Response to an Escherichia coli K88 oral challenge and productivity of weanling pigs receiving a dietary nucleotides supplement. J Anim Sci Biotechnol. (2015) 6:1-9. doi: 10.1186/s40104-015-0049-5

113. Li S, Zheng J, Deng K, Chen L, Zhao XL, Jiang X, et al. Supplementation with organic acids showing different effects on growth performance, gut morphology, and microbiota of weaned pigs fed with highly or less digestible diets. J Anim Sci. (2018) 96:3302-18. doi: 10.1093/jas/sky197

114. Deng Q, Shao Y, Wang Q, Li J, Li Y, Ding X, et al. Effects and interaction of dietary electrolyte balance and citric acid on the intestinal function of weaned piglets. J Anim Sci. (2020) 98:skaa106. doi: 10.1093/jas/skaa106

115. Long SF, Xu YT, Pan L, Wang QQ, Wang CL, Wu JY, et al. Mixed organic acids as antibiotic substitutes improve performance, serum immunity, intestinal morphology and microbiota for weaned piglets. Anim Feed Sci Technol. (2018) 235:23-32. doi: 10.1016/j.anifeedsci.2017.08.018

116. Liu Y, Che TM, Song M, Lee JJ, Almeida JAS, Bravo D, et al. Dietary plant extracts improve immune responses and growth efficiency of pigs experimentally infected with porcine reproductive and respiratory syndrome virus. J Anim Sci. (2013) 91:5668-79. doi: 10.2527/jas.2013-6495

117. Blavi L, Solà-Oriol D, Mallo JJ, Pérez JF. Anethol, cinnamaldehyde, and eugenol inclusion in feed affects postweaning performance and feeding behavior of piglets. J Anim Sci. (2016) 94:5262-71. doi: $10.2527 /$ jas.2016-0760

118. Li P, Piao X, Ru Y, Han X, Xue L, Zhang H. Effects of adding essential oil to the diet of weaned pigs on performance, nutrient utilization, immune response and intestinal health. Asian-Australasian J Anim Sci. (2012) 25:1617-26. doi: 10.5713/ajas.2012.12292

119. Kroismayr A, Sehm J, Pfaffl MW, Schedle K, Plitzner C, Windisch WM. Effects of avilamycin and essential oils on mRNA expression of apoptotic and inflammatory markers and gut morphology of piglets. Czech J Anim Sci. (2008) 53:377-87. doi: 10.17221/338-cjas

120. Maenner K, Vahjen W, Simon O. Studies on the effects of essential-oilbased feed additives on performance, ileal nutrient digestibility, and selected bacterial groups in the gastrointestinal tract of piglets. J Anim Sci. (2011) 89:2106-12. doi: 10.2527/jas.2010-2950

121. Peace RM, Campbell J, Polo J, Crenshaw J, Russell L, Moeser A. Spray-dried porcine plasma influences intestinal barrier function, inflammation, and diarrhea in weaned pigs. J Nutr. (2011) 141:1312-7. doi: $10.3945 /$ jn. 110.136796

122. Nofrarías M, Manzanilla EG, Pujols J, Gibert X, Majó N, Segalés J, et al. Spray-dried porcine plasma affects intestinal morphology and immune cell subsets of weaned pigs. Livest Sci. (2007) 108:299-302. doi: 10.1016/j.livsci.2007.01.103

123. Holanda DM, Kim SW. Efficacy of mycotoxin detoxifiers on health and growth of newly-weaned pigs under chronic dietary challenge of deoxynivalenol. Toxins. (2020) 12:311. doi: 10.3390/toxins12050311

124. Rao ZX, Tokach MD, Dritz SS, Woodworth JC, DeRouchey JM, Goodband $\mathrm{RD}$, et al. Efficacy of commercial products on growth performance of nursery pigs fed diets with fumonisin-contaminated corn. Kansas Agric Exp Stn Res Reports. (2019) 5:8. doi: 10.4148/2378-5977.7844

125. Sun Y, Park I, Guo J, Weaver AC, Kim SW. Impacts of low level aflatoxin in feed and the use of modified yeast cell wall extract on growth and health of nursery pigs. Anim Nutr. (2015) 1:177-83. doi: 10.1016/j.aninu.2015.08.012

126. Weaver AC, See MT, Kim SW. Protective effect of two yeast based feed additives on pigs chronically exposed to deoxynivalenol and zearalenone. Toxins. (2014) 6:3336-53. doi: 10.3390/toxins6123336

127. Pasupuleti VK, Braun S. State of the art manufacturing of protein hydrolysates. In: Pasupuleti VK, Demain AL, editors. Protein Hydrolysates in Biotechnology. Dordrecht: Springer Netherlands (2008). p. 11-32. doi: 10.1007/978-1-4020-6674-0_2

128. Hou Y, Wu Z, Dai Z, Wang G, Wu G. Protein hydrolysates in animal nutrition: industrial production, bioactive peptides, and functional significance. J Anim Sci Biotechnol. (2017) 8:1-13. doi: 10.1186/s40104-017-0153-9

129. Zhu X, Li D, Qiao S, Xiao C, Qiao Q, Ji C. Evaluation of HP300 soybean protein in starter pig diets. Asian-Aust J Anim Sci. (1998) 11:201-7. doi: 10.5713/ajas.1998.201

130. Hong KJ, Lee CH, Sung WK. Aspergillus oryzae GB-107 fermentation improves nutritional quality of food soybeans and feed soybean meals. J Med Food. (2004) 7:430-5. doi: 10.1089/jmf.2004.7.430

131. Mukherjee R, Chakraborty R, Dutta A. Role of fermentation in improving nutritional quality of soybean meal - a review. Asian-Australasian J Anim Sci. (2015) 29:1523-9. doi: 10.5713/ajas.15.0627

132. Daniel H. Molecular and integrative physiology of intestinal peptide transport. Annu Rev Physiol. (2004) 66:361-84. doi: 10.1146/annurev.physiol.66.032102.144149

133. Kim YG, Lohakare JD, Yun JH, Heo S, Chae BJ. Effect of feeding levels of microbial fermented soy protein on the growth performance, nutrient digestibility and intestinal morphology in weaned piglets. Asian-Australasian J Anim Sci. (2007) 20:399-404. doi: 10.5713/ajas.2007.399

134. Zhou SF, Sun ZW, Ma LZ, Yu JY, Ma CS, Ru YJ. Effect of feeding enzymolytic soybean meal on performance, digestion and immunity of weaned pigs. Asian-Australasian J Anim Sci. (2011) 24:103-9. doi: 10.5713/ajas.2011.10205

135. Koepke JR, Kaushik RS, Gibbons WR, Brown M, Levesque CL. Evaluation of a bioprocessed soybean meal on nursery pig performance and immune status. J Anim Sci. (2017) 95:5030-9. doi: 10.2527/jas2017.1679

136. Pierce JL, Cromwell GL, Lindemann MD, Russell LE, Weaver EM. Effects of spray-dried animal plasma and immunoglobulins on performance of early weaned pigs. J Anim Sci. (2005) 83:2876-85. doi: 10.2527/2005.83122876x

137. Chatterjee C, Gleddie S, Xiao CW. Soybean bioactive peptides and their functional properties. Nutrients. (2018) 10:8-11. doi: 10.3390/nu10091211

138. Nongonierma AB, FitzGerald RJ. Strategies for the discovery, identification and validation of milk protein-derived bioactive peptides. Trends Food Sci Technol. (2016) 50:26-43. doi: 10.1016/j.tifs.2016.01.022

139. Li DF, Nelssen JL, Reddy PG, Blecha F, Hancock JD, Allee GL, et al. Transient hypersensitivity to soybean meal in the early-weaned pig. J Anim Sci. (1990) 68:1790. doi: 10.2527/1990.6861790x

140. Baker DH. Nutritional constraints to the use of soy products by animals. In: Drackley JK, editor. Soy in Animal Nutrition. Savoy, IL: Federation of Animal Science Societies (2000). p. 1-12.

141. Taliercio E, Kim SW. Epitopes from two soybean glycinin subunits are antigenic in pigs. J Sci Food Agric. (2013) 93:2927-32. doi: 10.1002/jsfa.6113

142. Taliercio E, Kim SW. Identification of a second major antigenic epitope in the $\alpha$-subunit of soy $\beta$-conglycinin. Food Agric Immunol. (2014) 25:311-21. doi: 10.1080/09540105.2013.791969

143. Singh A, Meena M, Kumar D, Dubey AK, Hassan MI. Structural and functional analysis of various globulin proteins from soy seed. Crit Rev Food Sci Nutr. (2015) 55:1491-502. doi: 10.1080/10408398.2012.700340

144. Lallès JP. Soy products as protein sources for preruminants young pigs. In: Drackley JK, editor. Soy in Animal Nutrition. Savoy, IL: Federation of Animal Science Societies (2000). p. 106-26.

145. Li DF, Nelssen JL, Reddy PG, Blecha F, Klemm RD, Giesting DW, et al. Measuring suitability of soybean products for early-weaned pigs with immunological criteria. J Anim Sci. (1991) 69:3299-307. doi: $10.2527 / 1991.6983299 x$

146. Miller BG, Newby TJ, Stokes CR, Bourne FJ. Influence of diet on postweaning malabsorption and diarrhoea in the pig. Res Vet Sci. (1984) 36:187-93. doi: 10.1016/s0034-5288(18)31977-5

147. Taliercio E, Loveless TM, Turano MJ, Kim SW. Identification of epitopes of the $\beta$ subunit of soybean $\beta$-conglycinin that are antigenic in pigs, dogs, rabbits and fish. J Sci Food Agric. (2014) 94:2289-94. doi: 10.1002/ jsfa. 6556

148. Sun P, Li D, Li Z, Dong B, Wang F. Effects of glycinin on IgEmediated increase of mast cell numbers and histamine release in the small intestine. J Nutr Biochem. (2008) 19:627-33. doi: 10.1016/j.jnutbio.2007. 08.007 
149. Dréau D, Lallès JP, Philouze-Romé V, Toullec R, Salmon H. Local and systemic immune responses to soybean protein ingestion in early-weaned pigs. J Anim Sci. (1994) 72:2090-8. doi: 10.2527/1994.7282090x

150. Cervantes-Pahm SK, Stein HH. Ileal digestibility of amino acids in conventional, fermented, and enzyme-treated soybean meal and in soy protein isolate, fish meal, and casein fed to weanling pigs. J Anim Sci. (2010) 88:2674-83. doi: 10.2527/jas.2009-2677

151. Middelbos IS, Fahey GC. Soybean carbohydrates. In: Johnson L, White P, Galloway R, editors. Soybeans: Chemistry, Production, Processing, Utilization. Urbana, IL: Academic Press and AOCS Press (2008). p. 269-96.

152. Maebuchi M, Samoto M, Kohno M, Ito R, Koikeda T, Hirotsuka M, et al. Improvement in the intestinal absorption of soy protein by enzymatic digestion to oligopeptide in healthy adult men. Food Sci Technol Res. (2007) 13:45-53. doi: $10.3136 /$ fstr.13.45

153. Kodera T, Hara H, Nishimori Y, Nio N. Amino acid absorption in portal blood after duodenal infusions of a soy protein hydrolysate prepared by a novel soybean protease D3. J Food Sci. (2006) 71:S517-25. doi: 10.1111/j.1750-3841.2006.00118.x

154. Alder-Nissen J. Relationship of structure to taste of peptides peptide mixtures. In: Feeney RE, Whitaker JR, editors. Protein Tailoring for Food Medical Uses. New York, NY: Marcel Dekker (1986). p. 97-112.

155. Kim IM-R, Kawamura Y, Lee C-H. Isolation and identification of bitter peptides of tryptic hydrolysate of soybean 11 s glycinin by reverse-phase high-performance liquid chromatography. J Food Sci. (2003) 68:2416-22. doi: 10.1111/j.1365-2621.2003.tb07039.x

156. Nishiwaki T, Hayashi K. Purification and characterization of an aminopeptidase from the edible basidiomycete grifola frondosa. Biosci Biotechnol Biochem. (2001) 65:424-7. doi: 10.1271/bbb.65.424

157. Matoba T, Hata T. Relationship between bitterness of peptides and their chemical structures. Agric Biol Chem. (1972) 36:1423-31. doi: 10.1080/00021369.1972.10860410

158. Nishiwaki T, Yoshimizu S, Furuta M, Hayashi K. Debittering of enzymatic hydrolysates using an aminopeptidase from the edible basidiomycete Grifola frondosa. J Biosci Bioeng. (2002) 93:60-3. doi: 10.1016/S1389-1723(02)80055-X

159. deMan JM, Bowland JP. Fatty acid composition of sow's colostrum, milk and body fat as determined by gas-liquid chromatography. J Dairy Res. (1963) 30:339-43. doi: 10.1017/S0022029900011523

160. Hurley WL. Composition of sow colostrum milk. In: Farmer C, editor. The Gestating Lactating Sow. Wageningen: Wageningen Academic Publishers (2015). p. 193-230. doi: 10.3920/978-90-8686-803-2

161. Maxwell CVJ, Carter SD. Feeding the Weaned Pig. In: Lewis AJ, Southern LL, editors. Swine Nutrition. Boca Raton, FL: CRC Press (2001). p. 691-715.

162. Frobish LT, Hays VW, Speer VC, Ewan RC. Effect of diet form and emulsifying agents on fat utilization by young pigs. J Anim Sci. (1969) 29:320-4. doi: 10.2527/jas1969.292320x

163. Frobish LT, Hays VW, Speer VC, Ewan RC. Effect of fat source and level on utilization of fat by young pigs. J Anim Sci. (1970) 30:197-202. doi: $10.2527 /$ jas $1970.302197 x$

164. Wiseman J. Assessment of the digestible metabolizable energy of fats for non- ruminants. In: Wiseman J, editor. Fats in Animal Nutrition. Butterworth-Heinemann: Elsevier (1984). p. 277-297. doi: 10.1016/B978-0-408-10864-5.50020-6

165. Salentinig S, Phan S, Khan J, Hawley A, Boyd BJ. Formation of highly organized nanostructures during the digestion of milk. ACS Nano. (2013) 7:10904-11. doi: 10.1021/nn405123j

166. Lewis DS, Oren S, Wang X, Moyer ML, Beitz DC, Knight TJ, et al. Developmental changes in cholesterol 7alpha- and 27-hydroxylases in the piglet. J Anim Sci. (2000) 78:943. doi: 10.2527/2000.784943x

167. Li J, Wang $\mathrm{X}$, Zhang T, Wang C, Huang Z, Luo X, et al. A review on phospholipids and their main applications in drug delivery systems. Asian J Pharm Sci. (2015) 10:81-98. doi: 10.1016/j.ajps.2014.09.004

168. Joshi A, Paratkar SG, Thorat BN. Modification of lecithin by physical, chemical and enzymatic methods. Eur J Lipid Sci Technol. (2006) 108:363-73. doi: 10.1002/ejlt.200600016

169. van Nieuwenhuyzen W, Tomás MC. Update on vegetable lecithin and phospholipid technologies. Eur J Lipid Sci Technol. (2008) 110:472-86. doi: 10.1002/ejlt.200800041
170. Wendel A, By Staff U. Lecithin. In: Ley C, editor. Kirk-Othmer Encyclopedia of Chemical Technology. Hoboken, NJ: John Wiley \& Sons, Inc. (2014). p. 1-19. doi: 10.1002/0471238961.1205030923051404.a01.pub2

171. Cabezas DM, Diehl BWK, Tomás MC. Emulsifying properties of hydrolysed and low HLB sunflower lecithin mixtures. Eur J Lipid Sci Technol. (2016) 118:975-83. doi: 10.1002/ejlt.201500182

172. Pokorný J. Production, separation modification of phospholipids for use in food. In: Gunstone FD, editor. Modifying Lipids for Use in Food Woodhead publishing in Food Science, Technology Nutrition. Cambridge: Elsevier (2006). p. 369-90. doi: 10.1533/9781845691684.2.369

173. Estiasih T, Ahmadi K, Ginting E, Priyanto AD. Modification of soy crude lecithin by partial enzymatic hydrolysis using phosholipase A1. Int Food Res J. (2013) 20:843-9. Available online at: http://www.ifrj.upm.edu.my/20 \%20(02)\%202013/47\%20IFRJ\%2020\%20(02)\%202013\%20Teti\%20(055).pdf

174. Moolenaar WH. Bioactive lysophospholipids and their G protein-coupled receptors. Exp Cell Res. (1999) 253:230-8. doi: 10.1006/excr.1999.4702

175. Gardell SE, Dubin AE, Chun J. Emerging medicinal roles for lysophospholipid signaling. Trends Mol Med. (2006) 12:65-75. doi: 10.1016/j.molmed.2005.12.001

176. Choi JW, Chun J. Lysophospholipids and their receptors in the central nervous system. Biochim Biophys Acta - Mol Cell Biol Lipids. (2013) 1831:2032. doi: 10.1016/j.bbalip.2012.07.015

177. Boontiam W, Jung B, Kim YY. Effects of lysophospholipid supplementation to lower nutrient diets on growth performance, intestinal morphology, and blood metabolites in broiler chickens. Poult Sci. (2017) 96:593-601. doi: $10.3382 / \mathrm{ps} /$ pew269

178. Hines OJ, Ryder N, Chu J, McFadden D. Lysophosphatidic acid stimulates intestinal restitution via cytoskeletal activation and remodeling. J Surg Res. (2000) 92:23-8. doi: 10.1006/jsre.2000.5941

179. Sturm A, Sudermann T, Schulte K, Goebell H, Dignass AU. Modulation of intestinal epithelial wound healing in vitro and in vivo by lysophosphatidic acid. Gastroenterology. (1999) 117:368-77. doi: 10.1053/gast.1999.0029900368

180. Khonyoung D, Yamauchi K, Suzuki K. Influence of dietary fat sources and lysolecithin on growth performance, visceral organ size, and histological intestinal alteration in broiler chickens. Livest Sci. (2015) 176:111-20. doi: 10.1016/j.livsci.2015.03.011

181. Berding K, Wang M, Monaco MH, Alexander LS, Mudd AT, Chichlowski M, et al. Prebiotics and bioactive milk fractions affect gut development, microbiota, and neurotransmitter expression in piglets. J Pediatr Gastroenterol Nutr. (2016) 63:688-97. doi: 10.1097/MPG.0000000000001200

182. Gibson GR, Roberfroid MB. Dietary modulation of the human colonic microbiota: introducing the concept of prebiotics. J Nutr. (1995) 125:140112. doi: $10.1093 / \mathrm{jn} / 125.6 .1401$

183. Bindels LB, Delzenne NM, Cani PD, Walter J. Towards a more comprehensive concept for prebiotics. Nat Rev Gastroenterol Hepatol. (2015) 12:303-10. doi: 10.1038/nrgastro.2015.47

184. Castillo M, Martín-Orúe SM, Taylor-Pickard JA, Pérez JF, Gasa J. Use of mannan-oligosaccharides and zinc chelate as growth promoters and diarrhea preventative in weaning pigs: effects on microbiota and gut function. J Anim Sci. (2008) 86:94-101. doi: 10.2527/jas.2005-686

185. Schokker D, Fledderus J, Jansen R, Vastenhouw SA, de Bree FM, Smits MA, et al. Supplementation of fructooligosaccharides to suckling piglets affects intestinal microbiota colonization and immune development. J Anim Sci. (2018) 96:2139-53. doi: 10.1093/jas/sky110

186. Lépine AFP, Konstanti P, Borewicz K, Resink JW, de Wit NJ, Vos $\mathrm{P}$ de, et al. Combined dietary supplementation of long chain inulin and Lactobacillus acidophilus W37 supports oral vaccination efficacy against Salmonella typhimurium in piglets. Sci Rep. (2019) 9:1-13. doi: 10.1038/s41598-019-54353-1

187. Xing Y, Li K, Xu Y, Wu Y, Shi L, Guo S, et al. Effects of galactooligosaccharide on growth performance, feacal microbiota, immune response and antioxidant capability in weaned piglets. J Appl Anim Res. (2020) 48:63-9. doi: 10.1080/09712119.2020.1732394

188. Quintero M, Maldonado M, Perez-Munoz M, Jimenez R, Fangman T, Rupnow J, et al. Adherence inhibition of cronobacter sakazakii to intestinal epithelial cells by prebiotic oligosaccharides. Curr Microbiol. (2011) 62:144854. doi: 10.1007/s00284-011-9882-8 
189. Zenhom M, Hyder A, de Vrese M, Heller KJ, Roeder T, Schrezenmeir J. Prebiotic oligosaccharides reduce proinflammatory cytokines in intestinal caco-2 cells via activation of PPAR $\gamma$ and peptidoglycan recognition protein 3. J Nutr. (2011) 141:971-7. doi: 10.3945/jn.110. 136176

190. Rossi M, Corradini C, Amaretti A, Nicolini M, Pompei A, Zanoni $\mathrm{S}$, et al. Fermentation of fructooligosaccharides and inulin by bifidobacteria: a comparative study of pure and fecal cultures. Appl Environ Microbiol. (2005) 71:6150-8. doi: 10.1128/AEM.71.10.6150-6158. 2005

191. Scott KP, Martin JC, Duncan SH, Flint HJ. Prebiotic stimulation of human colonic butyrate-producing bacteria and bifidobacteria, in vitro. FEMS Microbiol Ecol. (2014) 87:30-40. doi: 10.1111/1574-6941. 12186

192. Shi CX, Liu ZY, Shi M, Li P, Zeng ZK, Liu L, et al. Prediction of digestible and metabolizable energy content of rice bran fed to growing pigs. Asian-Australasian J Anim Sci. (2015) 28:654-61. doi: 10.5713/ajas.14. 0507

193. Fan L, Huang R, Wu C, Cao Y, Du T, Pu G, et al. Defatted rice bran supplementation in diets of finishing pigs: effects on physiological, intestinal barrier, and oxidative stress parameters. Animals. (2020) 10:449. doi: 10.3390/ani10030449

194. Supriyati, Haryati T, Susanti T, Susana IWR. Nutritional value of rice bran fermented by Bacillus amyloliquefaciens and humic substances and its utilization as a feed ingredient for broiler chickens. Asian-Australasian J Anim Sci. (2014) 28:231-8. doi: 10.5713/ajas.14.0039

195. Kompiang IP, Sinurat AP, Purwadaria T, Darma J. Cassapro in broiler ration: interaction with rice bran. J Ilmu Ternak dan Vet. (1995) 1:86-8. doi: 10.14334/JITV.V1I2.15

196. Henderson AJ, Kumar A, Barnett B, Dow SW, Ryan EP. Consumption of rice bran increases mucosal immunoglobulin a concentrations and numbers of intestinal Lactobacillus spp. J Med Food. (2012) 15:469-75. doi: $10.1089 /$ jmf.2011.0213

197. Monsan P, Paul F. Enzymatic synthesis of oligosaccharides. FEMS Microbiol Rev. (1995) 16:187-92. doi: 10.1111/j.1574-6976.1995.tb00165.x

198. Kurdi P, Hansawasdi C. Assessment of the prebiotic potential of oligosaccharide mixtures from rice bran and cassava pulp. LWT - Food Sci Technol. (2015) 63:1288-93. doi: 10.1016/j.lwt.2015.04.031

199. Bourlioux P, Koletzko B, Guarner F, Braesco V. The intestine and its microflora are partners for the protection of the host: report on the danone symposium "the intelligent intestine," held in paris, june 14, 2002. Am J Clin Nutr. (2003) 78:675-83. doi: 10.1093/ajcn/78.4.675

200. Simon O. The mode of action of NSP hydrolysing enzymes in the gastrointestinal tract. J Anim Feed Sci. (1998) 7:115-23. doi: $10.22358 /$ jafs $/ 69959 / 1998$

201. Ouwehand AC, Kirjavainen PV, Grönlund M-M, Isolauri E, Salminen SJ. Adhesion of probiotic micro-organisms to intestinal mucus. Int Dairy J. (1999) 9:623-30. doi: 10.1016/S0958-6946(99)00132-6

202. Herich R, Levkut M. Lactic acid bacteria, probiotics and immune system. Vet Med. (2002) 47:169-80. doi: 10.17221/5821-VETMED

203. Simon O. Micro-organisms as feed additives-probiotics. Adv Pork Prod. (2005) 16:161-7. Available online at: https://www.banffpork.ca/documents/ BO07-SimonO.pdf

204. Markowiak P, Slizewska K. The role of probiotics, prebiotics and synbiotics in animal nutrition. Gut Pathog. (2018) 10:1-20. doi: 10.1186/s13099-018-0250-0

205. Pandey KR, Naik SR, Vakil B V. Probiotics, prebiotics and synbiotics- a review. J Food Sci Technol. (2015) 52:7577-87. doi: 10.1007/s13197-015-1921-1

206. Duarte ME, Tyus J, Kim SW. synbiotic effects of enzyme and probiotics on intestinal health and growth of newly weaned pigs challenged with enterotoxigenic F18+Escherichia coli. Front Vet Sci. (2020) 7:1-13. doi: $10.3389 /$ fvets.2020.00573

207. Tsilingiri K, Rescigno M. Postbiotics: what else? Benef Microbes. (2013) 4:101-7. doi: 10.3920/BM2012.0046

208. Collado MC, Vinderola G, Salminen S. Postbiotics: facts and open questions. A position paper on the need for a consensus definition. Benef Microbes. (2019) 10:711-9. doi: 10.3920/BM2019.0015
209. Arambel MJ, Kent BA. Effect of yeast culture on nutrient digestibility and milk yield response in early- to midlactation dairy cows. J Dairy Sci. (1990) 73:1560-3. doi: 10.3168/jds.S0022-0302(90)78825-X

210. Shen YB, Fellner V, Yoon I, Kim SW. Effects of dietary supplementation of Saccharomyces cerevisiae fermentation product to sows and their offspring on growth and meat quality. Transl Anim Sci. (2017) 1:45-53. doi: $10.2527 / \operatorname{tas} 2016.0005$

211. Meller RA, Wenner BA, Ashworth J, Gehman AM, Lakritz J, Firkins JL. Potential roles of nitrate and live yeast culture in suppressing methane emission and influencing ruminal fermentation, digestibility, and milk production in lactating jersey cows. J Dairy Sci. (2019) 102:6144-56. doi: 10.3168/jds.2018-16008

212. Shen YB, Piao XS, Kim SW, Wang L, Liu P, Yoon I, et al. Effects of yeast culture supplementation on growth performance, intestinal health, and immune response of nursery pigs. J Anim Sci. (2009) 87:2614-24. doi: $10.2527 /$ jas.2008-1512

213. Weedman SM, Rostagno MH, Patterson JA, Yoon I, Fitzner G, Eicher SD. Yeast culture supplement during nursing and transport affects immunity and intestinal microbial ecology of weanling pigs. J Anim Sci. (2011) 89:1908-21. doi: 10.2527/jas.2009-2539

214. Holanda DM, Yiannikouris A, Kim SW. Investigation of the efficacy of a postbiotic yeast cell wall-based blend on newly-weaned pigs under a dietary challenge of multiple mycotoxins with emphasis on deoxynivalenol. Toxins. (2020) 12:504. doi: 10.3390/toxins120 80504

215. Mathew AG, Chattin SE, Robbins CM, Golden DA. Effects of a directfed yeast culture on enteric microbial populations, fermentation acids, and performance of weanling pigs. J Anim Sci. (1998) 76:2138-45. doi: $10.2527 / 1998.7682138 x$

216. Kim SW, Baker DH. Use of enzyme supplements in pig diets based on soyabean meal. Pig News Inf. (2003) 24:91N-5. Available online at: https:// www.cabdirect.org/cabdirect/abstract/20033165301

217. Kim SW, Knabe DA, Hong KJ, Easter RA. Use of carbohydrases in corn-soybean meal-based nursery diets. J Anim Sci. (2003) 81:2496-504. doi: $10.2527 / 2003.81102496 \mathrm{x}$

218. Tiwari UP, Chen H, Kim SW, Jha R. Supplemental effect of xylanase and mannanase on nutrient digestibility and gut health of nursery pigs studied using both in vivo and in vitro models. Anim Feed Sci Technol. (2018) 245:77-90. doi: 10.1016/j.anifeedsci.2018. 07.002

219. Chen H, Zhang S, Park I, Kim SW. Impacts of energy feeds and supplemental protease on growth performance, nutrient digestibility, and gut health of pigs from 18 to $45 \mathrm{~kg}$ body weight. Anim Nutr. (2017) 3:359-65. doi: 10.1016/j.aninu.2017.09.005

220. Yin QQ, Zheng QH, Kang XT. Biochemical characteristics of phytases from fungi and the transformed microorganism. Anim Feed Sci Technol. (2007) 132:341-50. doi: 10.1016/j.anifeedsci.2006.03.016

221. Yáñez JL, Beltranena E, Cervantes M, Zijlstra RT. Effect of phytase and xylanase supplementation or particle size on nutrient digestibility of diets containing distillers dried grains with solubles cofermented from wheat and corn in ileal-cannulated grower pigs. J Anim Sci. (2011) 89:113-23. doi: $10.2527 /$ jas.2010-3127

222. Engelking LR. Nucleotides. In: Engelking LR, editor. Textbook of Veterinary Physiological Chemistry. Burlington, MA: Academic Press/Elsevier (2015). p. 78-82. doi: 10.1016/B978-0-12-391909-0.50013-X

223. Mateo CD, Peters DN, Stein HH. Nucleotides in sow colostrum and milk at different stages of lactation. J Anim Sci. (2004) 82:1339-42. doi: $10.2527 / 2004.8251339 \mathrm{x}$

224. Savaiano DA, Clifford AJ. Adenine, the precursor of nucleic acids in intestinal cells unable to synthesize purines de novo. J Nutr. (1981) 111:181622. doi: 10.1093/jn/111.10.1816

225. Martinez-Puig D, Manzanilla EG, Morales J, Borda E, Pérez JF, Piñeiro C, et al. Dietary nucleotide supplementation reduces occurrence of diarrhoea in early weaned pigs. Livest Sci. (2007) 108:276-9. doi: 10.1016/j.livsci.2007.01.099

226. Sauer N, Mosenthin R, Bauer E. The role of dietary nucleotides in single-stomached animals. Nutr Res Rev. (2011) 24:46-59. doi: $10.1017 /$ S0954422410000326 
227. Thomlinson J, Lawrence T. Dietary manipulation of gastric $\mathrm{pH}$ in the prophylaxis of enteric disease in weaned pigs: some field observations. Vet Rec. (1981) 109:120-2. doi: 10.1136/vr.109.6.120

228. Risley CR, Kornegay ET, Lindemann MD, Wood CM, Eigel WN. Effect of feeding organic acids on selected intestinal content measurements at varying times postweaning in pigs. J Anim Sci. (1992) 70:196-206. doi: $10.2527 / 1992.701196 x$

229. Blank R, Mosenthin R, Sauer WC, Huang S. Effect of fumaric acid and dietary buffering capacity on ileal and fecal amino acid digestibilities in early-weaned pigs. J Anim Sci. (1999) 77:2974-84. doi: 10.2527/1999.77112974x

230. Partanen KH, Mroz Z. Organic acids for performance enhancement in pig diets. Nutr Res Rev. (1999) 12:117-45. doi: 10.1079/095442299108728884

231. Falkowski JF, Aherne FX. Fumaric and citric acid as feed additives in starter pig nutrition. J Anim Sci. (1984) 58:935-8. doi: 10.2527/jas1984.584935x

232. Henry RW, Pickard DW, Hughes PE. Citric acid and fumaric acid as food additives for early-weaned piglets. Anim Sci. (1985) 40:505-9. doi: $10.1017 /$ S0003356100040204

233. Tugnoli B, Giovagnoni G, Piva A, Grilli E. From acidifiers to intestinal health enhancers: how organic acids can improve growth efficiency of pigs. Animals. (2020) 10:1-18. doi: 10.3390/ani10010134

234. Suiryanrayna MVAN, Ramana J V. A review of the effects of dietary organic acids fed to swine. J Anim Sci Biotechnol. (2015) 6:1-11. doi: 10.1186/s40104-015-0042-z

235. Ren C, Zhou Q, Guan W, Lin X, Wang Y, Song H, et al. Immune response of piglets receiving mixture of formic and propionic acid alone or with either capric acid or bacillus licheniformis after Escherichia coli challenge. Biomed Res Int. (2019) 2019:6416187. doi: 10.1155/2019/6416187

236. Windisch W, Schedle K, Plitzner C, Kroismayr A. Use of phytogenic products as feed additives for swine and poultry. J Anim Sci. (2008) 86:E140-8. doi: $10.2527 /$ jas.2007-0459

237. Clouard C, Val-Laillet D. Impact of sensory feed additives on feed intake, feed preferences, and growth of female piglets during the early postweaning period. J Anim Sci. (2014) 92:2133-40. doi: 10.2527/jas.2013-6809

238. Platel K, Srinivasan K. Digestive stimulant action of spices: a myth or reality? Indian J Med Res. (2004) 119:167-79. Available online at: https://scinapse.io/ papers/105576669

239. Kommera SK, Mateo RD, Neher FJ, Kim SW. Phytobiotics and organic acids as potential alternatives to the use of antibiotics in nursery pig diets. AsianAustralasian J Anim Sci. (2006) 19:1784-89. doi: 10.5713/ajas.2006.1784

240. Remus A, Andretta I, Kipper M, Lehnen CR, Klein CC, Lovatto PA, et al. A meta-analytical study about the relation of blood plasma addition in diets for piglets in the post-weaning and productive performance variables. Livest Sci. (2013) 155:294-300. doi: 10.1016/j.livsci.2013.04.020

241. Torrallardona D, Conde MR, Badiola I, Polo J, Brufau J. Effect of fishmeal replacement with spray-dried animal plasma and colistin on intestinal structure, intestinal microbiology, and performance of weanling pigs challenged with Escherichia coli K99. J Anim Sci. (2003) 81:1220-6. doi: 10.2527/2003.8151220x

242. Bosi P, Casini L, Finamore A, Cremokolini C, Merialdi G, Trevisi $\mathrm{P}$, et al. Spray-dried plasma improves growth performance and reduces inflammatory status of weaned pigs challenged with enterotoxigenic Escherichia coli K88. J Anim Sci. (2004) 82:1764-72. doi: $10.2527 / 2004.8261764 \mathrm{x}$

243. Pereira CS, Cunha SC, Fernandes JO. Prevalent mycotoxins in animal feed: occurrence and analytical methods. Toxins. (2019) 11:290. doi: $10.3390 /$ toxins 11050290

244. Marin DE, Taranu I, Bunaciu RP, Pascale F, Tudor DS, Avram N, et al. Changes in performance, blood parameters, humoral and cellular immune responses in weanling piglets exposed to low doses of aflatoxin. J Anim Sci. (2002) 80:1250-7. doi: 10.2527/2002.8051250x

245. Rustemeyer SM, Lamberson WR, Ledoux DR, Rottinghaus GE, Shaw DP, Cockrum RR, et al. Effects of dietary aflatoxin on the health and performance of growing barrows. J Anim Sci. (2010) 88:3624-30. doi: $10.2527 /$ jas.2009-2663

246. Frobose HL, Fruge ED, Tokach MD, Hansen EL, Derouchey JM, Dritz SS, et al. The effects of deoxynivalenol-contaminated corn dried distillers grains with solubles in nursery pig diets and potential for mitigation by commercially available feed additives. J Anim Sci. (2015) 93:1074-88. doi: 10.2527/jas.2013-6883

247. Rao ZX, Tokach MD, Woodworth JC, DeRouchey JM, Goodband $\mathrm{RD}$, Calderón HI, et al. Effects of fumonisin-contaminated corn on growth performance of 9 to $28 \mathrm{~kg}$ nursery pigs. Toxins. (2020) 12:1-11. doi: 10.3390/toxins 12090604

248. Terciolo C, Bracarense AP, Souto PCMC, Cossalter AM, Dopavogui $\mathrm{L}$, Loiseau $\mathrm{N}$, et al. Fumonisins at doses below EU regulatory limits induce histological alterations in piglets. Toxins. (2019) 11:1-14. doi: $10.3390 /$ toxins 11090548

249. Stoev SD, Paskalev M, MacDonald S, Mantle PG. Experimental one year ochratoxin A toxicosis in pigs. Exp Toxicol Pathol. (2002) 53:481-7. doi: 10.1078/0940-2993-00213

250. Jiang SZ, Yang ZB, Yang WR, Wang SJ, Liu FX, Johnston LA, et al. Effect of purified zearalenone with or without modified montmorillonite on nutrient availability, genital organs and serum hormones in post-weaning piglets. Livest Sci. (2012) 144:110-8. doi: 10.1016/j.livsci.2011.11.004

251. Yang L, Yang W, Feng Q, Huang L, Zhang G, Liu F, et al. Effects of purified zearalenone on selected immunological measurements of blood in postweaning gilts. Anim Nutr. (2016) 2:142-8. doi: 10.1016/j.aninu.2016.04.008

252. Oswald IP, Desautels C, Laffitte J, Fournout S, Peres SY, Odin M, et al. Mycotoxin fumonisin B1 increases intestinal colonization by pathogenic Escherichia coli in pigs. Appl Environ Microbiol. (2003) 69:5870-4. doi: 10.1128/AEM.69.10.5870-5874.2003

253. Pierron A, Alassane-Kpembi I, Oswald IP. Impact of two mycotoxins deoxynivalenol and fumonisin on pig intestinal health. Porc Heal Manag. (2016) 2:1-8. doi: 10.1186/s40813-016-0041-2

254. Pinton P, Braicu C, Nougayrede J-P, Laffitte J, Taranu I, Oswald IP. Deoxynivalenol impairs porcine intestinal barrier function and decreases the protein expression of claudin-4 through a mitogenactivated protein kinase-dependent mechanism. J Nutr. (2010) 140:1956-62. doi: 10.3945/jn.110.123919

255. Cano PM, Seeboth J, Meurens F, Cognie J, Abrami R, Oswald IP, et al. Deoxynivalenol as a new factor in the persistence of intestinal inflammatory diseases: an emerging hypothesis through possible modulation of Th17-mediated response. PLoS ONE. (2013) 8:e53647. doi: 10.1371/journal.pone.0053647

256. Serviento AM, Brossard L, Renaudeau D. An acute challenge with a deoxynivalenol-contaminated diet has short- and longterm effects on performance and feeding behavior in finishing pigs. J Anim Sci. (2018) 96:5209-21. doi: 10.1093/jas/sky378

257. Rotter BA, Prelusky DB, Pestka JJ. Toxicology of deoxynivalenol (vomitoxin). J Toxicol Environ Health. (1996) 48:1-34. doi: 10.1080/009841096161447

258. Bouhet S, Oswald IP. The effects of mycotoxins, fungal food contaminants, on the intestinal epithelial cell-derived innate immune response. Vet Immunol Immunopathol. (2005) 108:199-209. doi: $10.1016 /$ j.vetimm.2005.08.010

259. Van De Walle J, Sergent T, Piront N, Toussaint O, Schneider Y-J, Larondelle Y. Deoxynivalenol affects in vitro intestinal epithelial cell barrier integrity through inhibition of protein synthesis. Toxicol Appl Pharmacol. (2010) 245:291-8. doi: 10.1016/j.taap.2010.03.012

260. Hahn I, Kunz-Vekiru E, Twaruzek M, Grajewski J, Krska R, Berthiller F. Aerobic and anaerobic in vitro testing of feed additives claiming to detoxify deoxynivalenol and zearalenone. Food Addit Contam Part A. (2015) 32:92233. doi: 10.1080/19440049.2015.1023741

261. Zitomer NC, Mitchell T, Voss KA, Bondy GS, Pruett ST, GarnierAmblard EC, et al. Ceramide synthase inhibition by fumonisin b 1 causes accumulation of 1-deoxysphinganine. J Biol Chem. (2009) 284:4786-95. doi: $10.1074 /$ jbc.M808798200

262. Wang E, Norred WP, Bacon CW, Riley RT, Merrill AHJ. Inhibition of sphingolipid biosynthesis by fumonisins. Food Chem Toxicol. (1991) 266:14486-90.

263. Merrill AHJ, Sullards MC, Wang E, Voss KA, Riley RT. Sphingolipid metabolism: roles in signal transduction and disruption by fumonisins. Environ Health Perspect. (2001) 109:283-9. doi: 10.1289/ehp.01109 s2283 
264. Grenier B, Applegate T. Modulation of intestinal functions following mycotoxin ingestion: meta-analysis of published experiments in animals. Toxins. (2013) 5:396-430. doi: 10.3390/toxins502 0396

265. Haschek WM, Gumprecht LA, Smith G, Tumbleson ME, Constable PD. Fumonisin toxicosis in swine: an overview of porcine pulmonary edema and current perspectives. Environ Health Perspect. (2001) 109:251-7. doi: 10.1289/ehp.01109s 2251

266. CAST. Mycotoxins: Risks in Plant, Animal, and Human Systems. Ames, IA (2003).
Conflict of Interest: The authors declare that the research was conducted in the absence of any commercial or financial relationships that could be construed as a potential conflict of interest.

Copyright (c) 2021 Zheng, Duarte, Sevarolli Loftus and Kim. This is an open-access article distributed under the terms of the Creative Commons Attribution License (CC $B Y)$. The use, distribution or reproduction in other forums is permitted, provided the original author(s) and the copyright owner(s) are credited and that the original publication in this journal is cited, in accordance with accepted academic practice. No use, distribution or reproduction is permitted which does not comply with these terms. 